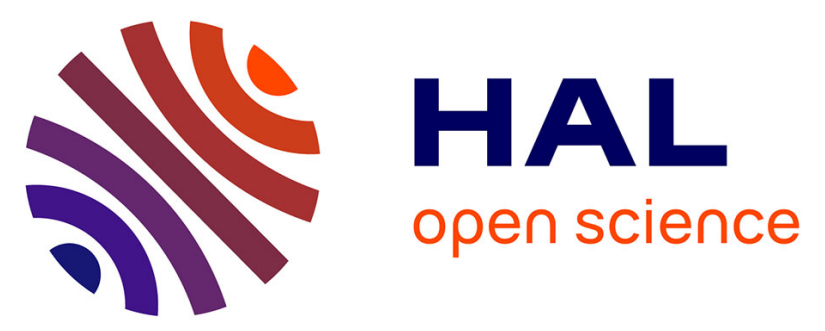

\title{
Characteristics and sources of nitrous acid in an urban atmosphere of northern China: Results from 1-yr continuous observations
}

\author{
Dandan Li, Likun Xue, Liang Wen, Xinfeng Wang, Tianshu Chen, \\ Abdelwahid S Mellouki, Jianmin Chen, Wenxing Wang
}

\section{To cite this version:}

Dandan Li, Likun Xue, Liang Wen, Xinfeng Wang, Tianshu Chen, et al.. Characteristics and sources of nitrous acid in an urban atmosphere of northern China: Results from 1-yr continuous observations. Atmospheric Environment, 2018, 182, pp.296-306. 10.1016/j.atmosenv.2018.03.033 . insu-01744529

HAL Id: insu-01744529

https://hal-insu.archives-ouvertes.fr/insu-01744529

Submitted on 27 Mar 2018

HAL is a multi-disciplinary open access archive for the deposit and dissemination of scientific research documents, whether they are published or not. The documents may come from teaching and research institutions in France or abroad, or from public or private research centers.
L'archive ouverte pluridisciplinaire HAL, est destinée au dépôt et à la diffusion de documents scientifiques de niveau recherche, publiés ou non, émanant des établissements d'enseignement et de recherche français ou étrangers, des laboratoires publics ou privés. 


\section{Accepted Manuscript}

ATMOSPHERIC ENVIRONMENT

Characteristics and sources of nitrous acid in an urban atmosphere of northern China: Results from 1-yr continuous observations

Dandan Li, Likun Xue, Liang Wen, Xinfeng Wang, Tianshu Chen, Abdelwahid Mellouki, Jianmin Chen, Wenxing Wang

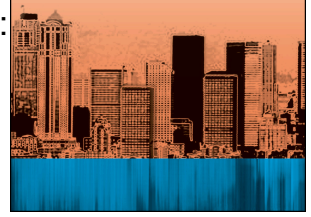

PII:

S1352-2310(18)30185-7

DOI:

10.1016/j.atmosenv.2018.03.033

Reference: $\quad$ AEA 15903

To appear in: Atmospheric Environment

Received Date: 13 July 2017

Revised Date: 27 February 2018

Accepted Date: 18 March 2018

Please cite this article as: Li, D., Xue, L., Wen, L., Wang, X., Chen, T., Mellouki, A., Chen, J., Wang, W., Characteristics and sources of nitrous acid in an urban atmosphere of northern China: Results from 1-yr continuous observations, Atmospheric Environment (2018), doi: 10.1016/j.atmosenv.2018.03.033.

This is a PDF file of an unedited manuscript that has been accepted for publication. As a service to our customers we are providing this early version of the manuscript. The manuscript will undergo copyediting, typesetting, and review of the resulting proof before it is published in its final form. Please note that during the production process errors may be discovered which could affect the content, and all legal disclaimers that apply to the journal pertain. 
3 Dandan $\mathrm{Li}^{1}$, Likun Xue ${ }^{1 *}$, Liang Wen ${ }^{1}$, Xinfeng Wang ${ }^{1}$, Tianshu Chen ${ }^{1}$, Abdelwahid

4 Mellouki $^{1,2}$, Jianmin Chen ${ }^{1,3}$, and Wenxing Wang ${ }^{1}$

$5 \quad{ }^{1}$ Environment Research Institute, Shandong University, Ji’nan, Shandong, China

$6 \quad 2$ ICARE/OSUC, CNRS, 45071 Orléans, France

$7 \quad{ }^{3}$ Shanghai Key Laboratory of Atmospheric Particle Pollution and Prevention (LAP3), Fudan

8 Tyndall Center, Department of Environmental Science \& Engineering, Fudan University,

9 Shanghai, China

10

*Correspondence to:

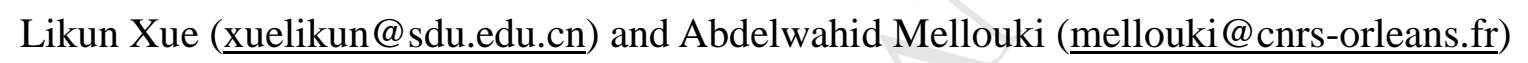

\section{Abstract}

Nitrous acid (HONO) is a key reservoir of the hydroxyl radical $(\mathrm{OH})$ and plays a central role in the atmospheric chemistry. To understand the sources and impact of HONO in the polluted atmosphere of northern China, continuous measurements of HONO and related parameters were conducted from September 2015 to August 2016 at an urban site in Ji'nan, the capital city of Shandong province. HONO showed well-defined seasonal and diurnal variation patterns with clear wintertime and nighttime concentration peaks. Elevated HONO concentrations (e.g., over 5 ppbv) were frequently observed with a maximum value of 8.36 ppbv. The $\mathrm{HONO} / \mathrm{NO}_{\mathrm{X}}$ ratios of direct vehicle emissions varied in the range of $0.29 \%-0.87 \%$, with a mean value of $0.53 \%$. An average $\mathrm{NO}_{2}$-to-HONO nighttime conversion frequency $\left(\mathrm{k}_{\text {het }}\right)$ was derived to be $0.0068 \pm 0.0045 \mathrm{~h}^{-1}$ from $107 \mathrm{HONO}$ formation cases. A detailed HONO budget analysis suggests an unexplained daytime missing source of $2.95 \mathrm{ppb} \mathrm{h}^{-1}$ in summer, which is about seven times larger than the homogeneous reaction of $\mathrm{NO}$ with $\mathrm{OH}$. The effect of $\mathrm{HONO}$ on $\mathrm{OH}$ production was also quantified. HONO photolysis was the uppermost source of local $\mathrm{OH}$ radical throughout the daytime. This study provides the year-round 
continuous record of ambient HONO in the North China Plain, and offers some insights into the characteristics, sources and impacts of HONO in the polluted atmospheres of China.

Keywords: Nitrous acid, Seasonal variation, Heterogeneous conversion, Atmospheric oxidizing capacity, North China Plain

\section{Introduction}

Nitrous acid (HONO) is a key precursor of the hydroxyl radical $(\mathrm{OH})$, one of the main tropospheric oxidants in the gas phase. Numerous field and modeling studies have shown that HONO photolysis contributes significantly to the $\mathrm{OH}$ sources not only in the early morning but also during the rest of the daytime (Acker et al., 2006b; Kleffmann et al., 2005; Xue et al., 2016). This is mainly ascribed to the unexpectedly high concentrations of HONO during daytime which would have been kept at lower levels due to its rapid photolysis (R1). Therefore, the knowledge of characteristics and sources of HONO is critical for a better understanding of the tropospheric oxidation chemistry processes.

$$
\mathrm{HONO}+h v \rightarrow \mathrm{OH}+\mathrm{NO}(320 \mathrm{~nm}<\lambda<400 \mathrm{~nm})
$$

So far, field observations of HONO have been carried out at remote, rural and urban areas. The reported ambient concentrations rang from several pptv up to 15 ppbv (e.g., Beine et al., 2006; Elshorbany et al., 2009; Zhou et al., 2001). However, the potential sources that could explain the observed elevated daytime HONO are still under controversial discussion. The well accepted HONO sources include direct emissions from vehicle exhaust (Kurtenbach et al., 2001) and homogeneous gas phase reaction of NO with OH (R2) (Pagsberg et al., 1997).

$$
\mathrm{NO}+\mathrm{OH}+\mathrm{M} \rightarrow \mathrm{HONO}+\mathrm{M}
$$

Heterogeneous reactions of $\mathrm{NO}_{2}$ occurring on wet surfaces (R3) have been also proposed as an important source of HONO according to both laboratory studies and field observations (e.g., Finlayson-Pitts et al., 2003). Nonetheless, the source strength of reaction (R3) has not been accurately quantified and relies on the $\mathrm{NO}_{2}$ concentrations, surface area density and water content (Finlayson-Pitts et al., 2003). These reactions could occur on various types of 
surfaces including ground, buildings, vegetation, and aerosol surfaces (Liu et al., 2014; VandenBoer et al., 2013). Up to now, the contribution of the ground surfaces to the overall production of HONO is still under discussion and subject to intensive research activity (Wong et al., 2011; Zhang et al., 2016).

$$
2 \mathrm{NO}_{2}+\mathrm{H}_{2} \mathrm{O} \rightarrow \mathrm{HONO}+\mathrm{HNO}_{3(\mathrm{ads})}
$$

In addition, the heterogeneous reduction of $\mathrm{NO}_{2}$ on soot particles, mineral dust, and surfaces containing organic substrates was also proposed as a source of HONO (R4) (Ammann et al., 1998 and 2005; Ma et al., 2017), and these processes can be further photo-enhanced during the daytime (George et al., 2005; Monge et al., 2010; Ndour et al., 2008; Stemmler et al., 2006). Although the heterogeneous $\mathrm{NO}_{2}$ conversion on soot surfaces has high potential to produce $\mathrm{HONO}$, it decreases rapidly with aging and is usually regarded to be less important for ambient HONO formation (Han et al., 2013).

$$
\mathrm{NO}_{2}+\mathrm{HC}_{\text {red }} \rightarrow \mathrm{HONO}+\mathrm{HC}_{\mathrm{ox}}
$$

Besides, some other HONO sources have also been proposed, including soil emissions (Su et al., 2011), photolysis of adsorbed nitric acid $\left(\mathrm{HNO}_{3}\right)$ and nitrate $\left(\mathrm{NO}_{3}{ }^{-}\right)$at $\mathrm{UV}$ wavelengths of $300 \mathrm{~nm}$ (Zhou et al., 2001), and homogeneous reaction of $\mathrm{NO}_{2}$ with $\mathrm{HO}_{2} \cdot \mathrm{H}_{2} \mathrm{O}$ ( $\mathrm{Li}$ et al., 2014). Despite the abovementioned significant progress, the 'missing' daytime source(s) of atmospheric HONO is still under exploration.

In comparison with sources, the sink pathways of HONO are relatively well established. The chemical losses of HONO include the photolysis (R1) and reactions with $\mathrm{OH}$ radicals (R5). Moreover, HONO can be also removed through dry deposition on ground surfaces. Budget analysis of HONO sources and sinks has been proved to be a robust method to examine the unknown sources and quantify their source strength (Sörgel et al., 2011; Su et al., 2008b).

$$
\mathrm{HONO}+\mathrm{OH} \rightarrow \mathrm{H}_{2} \mathrm{O}+\mathrm{NO}_{2}
$$

A number of field studies have been conducted to measure ambient HONO in the polluted urban and rural atmospheres of China during the last decade. High concentration 
81 levels and strong potential missing source(s) of HONO have been reported in some metropolises (e.g., Beijing, Shanghai and Guangzhou) and surrounding regions (e.g., Bernard et al., 2016; Qin et al., 2009; Tong et al., 2016). However, most of these studies were mainly based on short-term intensive observations. While long-period measurements are necessary to support a holistic investigation of characteristics and sources of HONO, they are very scarce (Hendrick et al., 2014). In the present study, we have carried out 1-yr continuous observations of HONO and related parameters at an urban site of Ji'nan city, which is located almost in the center of the North China Plain (NCP), the most polluted region of China with dense population and industries. A large amount of observational data and HONO formation cases provided an opportunity of a thorough examination of temporal variations, sources and impacts of HONO in this polluted urban atmosphere of northern China. In the following sections, we will first show the seasonal and diurnal variations of HONO and related species. Then, several sources of HONO will be explored, including vehicle emission, nighttime heterogeneous formation and potential unknown daytime sources. We will finally evaluate the impacts of $\mathrm{HONO}$ photolysis on the primary $\mathrm{OH}$ sources and hence atmospheric oxidizing capacity.

\section{Experimental}

\subsection{Site description}

The measurements were conducted from September $1^{\text {st }} 2015$ to August $31^{\text {st }} 2016$ at an urban site of Ji'nan, the capital city of Shandong Province, with approximately 7 million population and 1.6 million automobiles. The site is located in the central campus of Shandong University $\left(36^{\circ} 40^{\prime} \mathrm{N}, 117^{\circ} 03^{\prime} \mathrm{E}\right)$, a typical urban area surrounded by massive buildings and condensed population and close to several main traffic roads (Fig.1). Large-scale industries, including steel plants, thermal power plants, cement plants, oil refineries and chemical plants in suburban areas are the major industrial emission sources of local air pollution in Ji'nan, and are mainly distributed in the northeast and southwest of the site. By observing the spikes of sulfur dioxide $\left(\mathrm{SO}_{2}\right)$ concentrations under northeasterly and/or southwesterly winds, we know that the site was affected by the local industrial emission sources. All the measurements were carried out on the rooftop of a six-floor teaching building, around $22 \mathrm{~m}$ above the 
110 ground level. A detailed description of the study site can be found elsewhere (Wang et al., $1112015)$.

\subsection{Measurement techniques}

HONO was measured by a commercial instrument of LOPAP (long path absorption photometer, QUMA GmbH, Germany). The LOPAP is a wet chemistry based real-time measurement device, with which HONO is sampled in an external sampling unit as a stable diazonium salt and is subsequently detected photo-metrically after conversion into an azodye in a long-path absorption tube of $2.4 \mathrm{~m}$ Teflon AF. The LOPAP is conceived as a 2-channel system to correct for the potential interferences. In channel $1, \mathrm{HONO}$ as well as possible interfering gases are determined, while in channel 2 only the interfering gases are quantified. The difference of both channels yields the HONO concentrations. A detailed description of the LOPAP instrument has been described in detail by Heland et al. (2001). In the present study, the sampling gas flow and the peristaltic pump velocity were set to $1 \mathrm{~L} \mathrm{~min}^{-1}$ and $20 \mathrm{r}$ min $^{-1}$ during the whole measurement period. With these settings, the HONO collection efficiency was ensured above $99.99 \%$. Zero air calibration by ultrapure nitrogen (purity of 99.999\%) was performed for $30 \mathrm{~min}$ automatically at a time interval of $12 \mathrm{~h} 30 \mathrm{~min}$. An experimental cycle of 8 days was calibrated twice manually by using a known concentration of nitrite $\left(\mathrm{NO}_{2}{ }^{-}\right)$standard solution. The detection limit of our measurements was 3 ppt at a time resolution of $30 \mathrm{~s}$, with an accuracy of $10 \%$ and a precision of $1 \%$. We note that although the LOPAP instrument may collect data in $30 \mathrm{~s}$ (or $1 \mathrm{~min}$ ) intervals, the physical time resolution of the instrument is relatively longer, ca. $3 \mathrm{~min}$.

The $\mathrm{NO}$ and $\mathrm{NO}_{2}$ concentrations were measured by a chemiluminescence $\mathrm{NO}-\mathrm{NO}_{2}-\mathrm{NO}_{\mathrm{X}}$ analyzer (Model 42C, TEC, USA) with a time resolution of 1 min, in which $\mathrm{NO}_{2}$ was converted to NO by a molybdenum oxide (MoO) catalytic converter. It should be noted that the $\mathrm{MoO}$ converters may also convert some $\mathrm{NOz}$ species to $\mathrm{NO}$ and hence overestimate the real $\mathrm{NO}_{2}$ concentrations. Xu et al. (2013) have indicated that such overestimation was usually significant in rural and remote areas but small at highly polluted urban sites with fresh emissions, such as the study site in the present study. $\mathrm{O}_{3}$ was measured by a commercial UV photometric $\mathrm{O}_{3}$ analyzer (Model 49C, TEC, USA) with a time resolution of $1 \mathrm{~min}$. The 
139 photolysis frequencies of $\mathrm{NO}_{2}, \mathrm{HONO}$ and $\mathrm{O}_{3}\left(\mathrm{~J}_{\mathrm{NO} 2}\right.$, J $\left.\mathrm{J}_{\mathrm{HONO}}, \mathrm{J}_{\mathrm{O} 3}\right)$ were measured by a

140 CCD-detector spectrometer (Metcon, Germany), with a time resolution of $1 \mathrm{~min}$. The fine 141 particle $\left(\mathrm{PM}_{2.5}\right.$ and $\left.\mathrm{PM}_{1.0}\right)$ mass concentrations were continuously measured by a SHARP Monitor (Model 5030; Thermo Fisher Scientific, USA). Beta rays attenuation and light scattering photometry were used to quantify the hourly average particle concentrations. The aerosol surface area density $\left(S / V_{a}\right)$ was calculated from the particle number size distributions between $5 \mathrm{~nm}$ and $10 \mu \mathrm{m}$, which were measured by a Wide-Range Particles Spectrometer (WPS, Model 1000XP, MSP Corporation, USA), by assuming that the particles are in spherical shape. The meteorological data including temperature, relative humidity (RH), and wind speed and direction were measured with an automatic meteorological station (CAWS6000, China) with a time resolution of $1 \mathrm{~min}$. All of the above measurement techniques have been successfully utilized in many previous studies (e.g., Wang et al., 2015; Xue et al., 2011) .

\section{Results and discussion}

\subsection{Data overview}

Figure 2 shows an overview of the measured HONO, NO, $\mathrm{NO}_{2}, \mathrm{PM}_{2.5}, \mathrm{PM}_{1.0}, \mathrm{~J}_{\mathrm{HONO}}$, and meteorological parameters in the present study. During the 1-yr measurement period, the prevailing winds were from the east and southwest sectors, indicating the general influence of industrial emissions on the study site (see Fig. 1). The air temperature ranged from $-15 \square$ to $39 \square$ with a mean value ( \pm standard deviation) of $16 \pm 11{ }^{\circ} \mathrm{C}$, and the relative humidity showed a clear seasonal variation pattern with higher levels in winter and summer. Markedly poor air quality was observed as expected. Throughout the 1-yr period, 137 haze episodes occurred with daily mass concentration of $\mathrm{PM}_{2.5}$ exceeding the National Ambient Air Quality Standard (Class II: $75 \mu \mathrm{g} \mathrm{m}^{-3}$ ), including 9 severe polluted haze episodes with daily average $\mathrm{PM}_{2.5}$ concentrations above $250 \mu \mathrm{g} \mathrm{m}^{-3}$. In addition, elevated levels of $\mathrm{NO}_{\mathrm{X}}$, i.e., up to $350 \mathrm{ppbv}$ of $\mathrm{NO}$ and 108 ppbv of $\mathrm{NO}_{2}$, were also frequently recorded, possibly as a result of intensive vehicle emissions nearby the study site. Overall, these observations highlight the nature of our measurement station as a typical polluted urban environment in North China. 
Table 1 documents the measured levels of HONO, NOx, HONO/NOx ratios and the comparison with the results obtained previously elsewhere. The measured HONO mixing ratios in Ji'nan ranged from $17 \mathrm{pptv}$ to $8.36 \mathrm{ppbv}$ with a mean $( \pm \mathrm{SD})$ value of $1.15 \pm 1.07 \mathrm{ppbv}$. Elevated HONO concentrations were frequently observed during the measurement period, with the daily maximum values exceeding 2 ppbv and 4 ppbv on 156 and 50 days, respectively (see Fig. 2). The maximum hourly value of 7.39 ppbv was recorded in the early morning of 6 December 2015. Such high levels of ambient HONO indicate the intense sources of HONO and potentially strong atmospheric oxidizing capacity in urban Ji'nan. The nighttime average (18:00-06:00, LT) HONO concentration was $1.28 \pm 1.16 \mathrm{ppbv}$, compared to the daytime average value (6:00-18:00, LT) of $0.99 \pm 0.95 \mathrm{ppbv}$. In particular, the mean HONO mixing ratio around noontime (11:00-13:00, LT) was even as high as 0.76 $\pm 0.61 \mathrm{ppbv}$, which is nearly the highest levels ever recorded in the urban atmospheres, and about $27 \%$ of the noontime HONO data were above $1.00 \mathrm{ppbv}$ during the measurement period. This implies the existence of strong daytime sources of HONO in the atmosphere of Ji'nan, which will be further discussed in Section 3.4.

The seasonal variations of ambient HONO and related parameters are depicted in Fig. 3. The highest concentrations of HONO occurred in winter (i.e., December-January), followed by spring (i.e., April-May), summer (especially August) and autumn, with seasonal mean $( \pm \mathrm{SD})$ values of $1.71 \pm 1.62,1.16 \pm 0.90,1.12 \pm 0.93$ and $0.78 \pm 0.60 \mathrm{ppbv}$, respectively. Overall, the seasonal variation of $\mathrm{HONO}$ coincided with that of $\mathrm{NO}_{2}$, an important precursor of HONO. Such measured seasonal pattern of HONO is different from those measured in Hong Kong (Xu et al., 2015) and Beijing (Hendrick et al., 2014), where the highest levels were found in the autumn season. The wintertime peak of ambient HONO in Ji'nan should be the result of the lower boundary layer height, weaker photolysis, and enhanced heterogeneous production of HONO given the more abundant $\mathrm{NO}_{2}$. The relatively higher springtime HONO mixing ratios might be related to some degree to the more intense heterogeneous reactions of $\mathrm{NO}_{2}$ on the surface of mineral particles (Nie et al., 2012), as indicated by the coincident higher concentrations of $\mathrm{NO}_{2}$ and $\mathrm{PM}_{2.5}$ (note that $\mathrm{PM}_{10}$ was not measured in the present study). Indeed, the air quality of Ji'nan in the spring of 2016 was characterized by high levels 
of particles and influenced by several dust storms and urban dust (http://www.sdein.gov.cn /dtxx/hbyw/201605/t20160512_294758.html). Besides, the elevated HONO levels in August under the condition of intense solar radiation suggests the presence of strong HONO sources as well as the important contributions of $\mathrm{HONO}$ as a potential source of $\mathrm{OH}$ radicals to the atmospheric oxidation chemistry.

The diurnal profiles of HONO and related supporting parameters are shown in Figure 4. Overall, the diurnal variations of HONO in different seasons were similar, which dropped rapidly after sunrise and reached a minimum at around 15:00 LT, and then increased and peaked during the morning rush hours (an exception is the winter case that showed a concentration peak at midnight). The diurnal variation trend of HONO was similar to that of NO, owing to a variety of chemical and physical processes, and the similar nighttime profiles suggest that vehicle emissions may pose a significant effect on the measured HONO levels. Such nighttime pattern was also found at Tung Chung, Hong Kong (Xu et al., 2015), a roadside site in Houston, U.S. (Rappenglück et al., 2013) and in a tunnel in Wuppertal, Germany (Kurtenbach et al., 2001). The average diurnal profiles of $\mathrm{HONO} / \mathrm{NO}_{2}$ ratio are also shown in Fig. 4f. The HONO/NO 2 ratio generally decreased after sunrise due to the increase of HONO photolysis, and then increased during the nighttime. An interesting finding was the second peak of $\mathrm{HONO} / \mathrm{NO}_{2}$ at around noontime in spring, summer and winter seasons. If the HONO sources during nighttime were the same as those at daytime, the minimum $\mathrm{HONO} / \mathrm{NO}_{2}$ ratios should be found at noon due to the strong photolysis of HONO. Thus, the higher ratios at noontime indicated the existence of additional daytime sources of HONO. Moreover, the $\mathrm{HONO} / \mathrm{NO}_{2}$ ratios increased with solar radiation (e.g., $\mathrm{J}_{\mathrm{HONO}}$ ), implying that the additional sources may be related to the solar radiation intensity. We will further discuss the potential daytime sources of HONO in Section 3.4.

\subsection{Contribution of vehicle emissions}

As our study site is close to several major roads of large traffic fleet, it is necessary to evaluate the contribution of vehicle emissions to the measured HONO concentrations. The $\mathrm{HONO} / \mathrm{NO}_{\mathrm{X}}$ ratio was usually chosen to derive the emission factor of HONO in the freshly emitted plumes (Kurtenbach et al., 2001). In order to ensure the fresh air masses, the 
following four criteria were adopted to select the cases: (a) only data in the morning rush hours (6:00-8:30 LT) in winter (e.g., November-February) were used; (b) $\mathrm{NO} / \mathrm{NO}_{\mathrm{X}}>0.7$; (c) good correlation between $\mathrm{HONO}$ and $\mathrm{NO}_{\mathrm{X}}$; (d) short duration of the plumes ( $<2$ hours). Rush hours are the prominent period with strong traffic emission and thus greatest contribution of vehicle exhaust to HONO concentrations. Furthermore, during the winter early morning rush hours when the solar radiation is weak and boundary layer height is relatively stable, the derived $\mathrm{HONO} / \mathrm{NOx}$ is less interfered by atmospheric photochemical reactions and mixing with the air masses aloft. Criteria (b) was used as an indicator for identifying the freshly emitted plumes. Criteria (c) and (d) further confirmed that the increase of HONO was mainly attributed to direct emissions instead of heterogeneous reactions of $\mathrm{NO}_{2}$. The slopes of the scatter plot of $\mathrm{HONO}$ versus $\mathrm{NO}_{\mathrm{X}}$ can be considered as the emission ratios. With such strict selection criteria, a total of twelve cases were screened out to estimate the vehicle emission factors of HONO in urban Ji'nan.

Table 2 summarizes the estimated emission factors of HONO/NOx for the 12 vehicular emission plumes. The average $\Delta \mathrm{NO} / \Delta \mathrm{NO}_{\mathrm{X}}$ ratio of the selected plumes was $94 \%$, indicating that the air masses were indeed freshly emitted. The correlation coefficients $\left(\mathrm{r}^{2}\right)$ of HONO with NOx varied case by case and were in the range of $0.58-0.96$, which may be due to the inevitable mixing of vehicle plumes with other air masses and/or heterogeneous conversion of $\mathrm{NO}_{2}$ on soot particles and ground surface. The derived $\Delta \mathrm{HONO} / \Delta \mathrm{NO}_{\mathrm{X}}$ ratios varied in the range of $0.19 \%-0.87 \%$, with an average value $( \pm \mathrm{SD})$ of $0.53 \% \pm 0.20 \%$. This is comparable to the emission factors obtained in Santiago, Chile (0.8\%; Elshorbany et al., 2009) and Wuppertal, Germany (0.3-0.8\%; Kurtenbach et al., 2001), but is substantially lower than those derived in Guangzhou (with a minimum value of 1.4\%; Qin et al., 2009) and Houston, U.S. (1.7\%; Rappengluck et al., 2013). The emission factors should be dependent on the types of vehicle engines, fuels and catalytic converters (Kurtenbach et al., 2001). The variance in the HONO/NOx ratios derived from different metropolitan areas highlights the necessity of examining the vehicular emission factors of HONO in the target city in the future studies. In the present study, the average $\mathrm{HONO} / \mathrm{NOx}$ value of $0.53 \%$ was adopted as the emission factor in urban Ji'nan, and was used to estimate the contributions of traffic 
emissions to the ambient nocturnal HONO levels (Equation 1) with a rough assumption that the observed NOx at our site was mainly emitted from vehicles.

$$
\mathrm{HONO}_{\mathrm{emis}}=\mathrm{NO}_{\mathrm{X}} \times 0.0053
$$

Where, $\mathrm{HONO}_{\text {emis }}$ is the $\mathrm{HONO}$ concentration arising from the direct vehicle emissions. The calculated $\mathrm{HONO}_{\mathrm{emis}}$ levels contributed on average $12 \%, 15 \%, 18 \%$ and $21 \%$ of the whole measured nighttime HONO concentrations in urban Ji'nan in spring, summer, autumn and winter, respectively.

\subsection{Heterogeneous conversion of $\mathrm{NO}_{2}$ to $\mathrm{HONO}$ during nighttime}

It has been widely accepted that the heterogeneous reactions of $\mathrm{NO}_{2}$ on wet surfaces present an important formation pathway of ambient HONO, and generally make a dominant contribution at nighttime (e.g., Finlayson-Pitts et al., 2003). To investigate the heterogeneous production of HONO in Ji'nan, a number of nighttime HONO formation cases were identified to estimate the $\mathrm{NO}_{2}$-to-HONO conversion frequency. The selected cases should meet the following criteria: (1) only the nighttime data in the absence of sunlight (i.e., 20:00-05:59 LT in autumn and winter and 20:00-04:59 LT in spring and summer) were used considering the fast HONO loss via photolysis and potential existence of unknown HONO sources at daytime; (2) both $\mathrm{HONO}$ concentrations and $\mathrm{HONO} / \mathrm{NO}_{2}$ ratios increased steadily during the target case; (3) the meteorological conditions, especially surface winds, should be stable. Figure 5 presents an example of the heterogeneous HONO formation case occurring on 6-7 September, 2015. In this case, the HONO mixing ratios increased rapidly after sunset from $0.08 \mathrm{ppbv}$ to $0.78 \mathrm{ppbv}$. Since the $\mathrm{HONO}$ concentrations and $\mathrm{HONO} / \mathrm{NO}_{2}$ almost increased linearly throughout the night, the slope fitted by the least linear regression for $\mathrm{HONO} / \mathrm{NO}_{2}$ ratios against time can be taken as the conversion frequency of $\mathrm{NO}_{2}$-to-HONO ( $\mathrm{k}_{\text {het }}$; also referred to as $\mathrm{C}_{\mathrm{HONO}}$ in other studies). During the 1-yr period, a total of 107 cases were finally selected. Such a large set of cases facilitated a more robust statistical analysis of the heterogeneous formation of HONO.

As our study site is close to the traffic roads, it is necessary to subtract the contribution from direct vehicle emissions. The emission ratio of $\mathrm{HONO} / \mathrm{NO}_{\mathrm{X}}$ derived in Section 3.2 was 
282 then used to adjust the HONO concentrations by $E q$. (2). The $\mathrm{NO}_{2}$-to-HONO conversion 283 frequency can be computed by $E q$. (3), by assuming that the increase of $\mathrm{HONO} / \mathrm{NO}_{2}$ ratio 284 was caused by the heterogeneous conversion (Su et al., 2008a; Xu et al., 2015).

$$
\mathrm{HONO}_{\text {corr }}=\mathrm{HONO}-\mathrm{NO}_{\mathrm{X}} \times 0.0053
$$

$$
\mathrm{k}_{\text {het }}=\frac{\frac{\left[\mathrm{HONO}_{\text {corr }}\right]\left(\mathrm{t}_{2}\right)}{\left[\mathrm{NO}_{2}\right]\left(\mathrm{t}_{2}\right)}-\frac{\left[\mathrm{HONO}_{\text {corr }}\right]\left(\mathrm{t}_{2}\right)}{\left[\mathrm{NO}_{2}\right]\left(\mathrm{t}_{1}\right)}}{\left(\mathrm{t}_{2}-\mathrm{t}_{1}\right)}
$$

287

The $k_{\text {het }}$ values derived from the 107 cases showed a large variability, from $0.0013 \mathrm{~h}^{-1}$ to $0.0194 \mathrm{~h}^{-1}$, with a mean value of $0.0068 \pm 0.0045 \mathrm{~h}^{-1}$. These results are well within the range of $\mathrm{k}_{\text {het }}$ obtained previously from other urban areas. For example, the $\mathrm{k}_{\text {het }}$ in Ji'nan is comparable to that derived at an urban site of Shanghai $\left(0.007 \mathrm{~h}^{-1}\right.$; Wang et al., 2013), and less than those in Guangzhou (0.016 h ${ }^{-1}$; Qin et al., 2009), Milan (0.012 $\mathrm{h}^{-1}$; Alicke et al., 2002) and Kathmandu (0.014 $\mathrm{h}^{-1}$; Yu et al., 2009). Figure 6 provides the seasonal variation of the $\mathrm{NO}_{2}$-to-HONO conversion rate in Ji'nan. Clearly, the largest average $\mathrm{k}_{\text {het }}$ was found in winter with a value of $0.0073 \pm 0.0044 \mathrm{~h}^{-1}$. This should be ascribed to the higher S/V surface density within the shallower boundary layer in the wintertime. Moreover, weak correlation $(R=0.07)$ between $k_{\text {het }}$ and aerosol surface density was also found, which suggests that the efficient heterogeneous formation of HONO may be independent on the aerosol surface.

The uptake coefficient of $\mathrm{NO}_{2}$ on various surfaces to yield $\mathrm{HONO}\left(\gamma_{\mathrm{NO}_{2} \rightarrow \mathrm{HONO}}\right)$ is a key parameter with large uncertainty in the air quality models to simulate $\mathrm{HONO}$ and $\mathrm{OH}$ radicals (Zhang et al., 2016). The overall $\gamma_{\mathrm{NO}_{2} \rightarrow \mathrm{HONO}}$ on the bulk surface of ground and particles can be estimated from Eq. (4).

$$
\begin{aligned}
& \mathrm{k}_{\text {het }}=\gamma_{\mathrm{NO}_{2} \rightarrow \mathrm{HONO}} \times \mathrm{c}_{\mathrm{NO}_{2}} \times\left(\frac{1}{4} \frac{\mathrm{s}}{\mathrm{V}_{\mathrm{a}}}+\frac{1}{8} \frac{\mathrm{s}}{\mathrm{v}_{\mathrm{g}}}\right) \\
& \frac{\mathrm{s}}{\mathrm{v}_{\mathrm{g}}}=\frac{2.2}{\mathrm{H}}
\end{aligned}
$$

Where, $c_{\mathrm{NO}_{2}}$ is the mean molecular velocity of $\mathrm{NO}_{2}\left(370 \mathrm{~m} \mathrm{~s}^{-1}\right) ; \mathrm{S} / V_{a}$ and $\mathrm{S} / V_{g}$ are the surface area to volume ratio $\left(\mathrm{m}^{-1}\right)$ for both aerosol and ground, respectively. Considering the land use of the study site, the ground was treated as an uneven surface, and a factor of 2.2 per unit ground surface measured by Voogt and Oke (1997) was adopted to calculate the total 
active surface. Hence, $\mathrm{S} / V_{g}$ can be calculated by $E q$. (5), where $\mathrm{H}$ is the mixing layer height and was obtained from the European Centre for Medium-Range Weather Forecasts (ECMRWF, ERA-Interim; http://apps.ecmwf.int/datasets/data/interim-full-daily/levtype=sfc/). The calculated uptake coefficients for the 107 cases varied in a wide range from $6.1 \times 10^{-8}$ to $1.7 \times 10^{-5}$, whilst the majority (5\%-95\% percentiles) fell in a narrower range of $1.1 \times 10^{-7}$ to $4.5 \times 10^{-6}$. The mean $\gamma_{\mathrm{NO} 2}$ value was $1.4 \pm 2.4 \times 10^{-6}$. Current laboratory studies have reported the range of $\gamma_{\mathrm{NO}_{2} \rightarrow \mathrm{HONO}}$ from $10^{-6}$ to $10^{-5}$ on the ground surface (Kurtenbach et al., 2001; VandenBoer et al., 2013) and from $10^{-7}$ to $10^{-5}$ on the aerosol surface (Ndour et al., 2008; Wong et al., 2011). Obviously, the uptake coefficient in different orders of magnitude would definitely lead to different assessment of the importance of heterogeneous HONO sources ( $\mathrm{Li}$ et al., 2010). The average uptake coefficient obtained from such a large set of samples could serve as a reference for modeling studies to simulate ambient $\mathrm{HONO}$ and atmospheric oxidation processes in the urban atmospheres of North China. Furthermore, the total area of ground surface is much larger than the reactive surface provided by aerosols, suggesting that the heterogeneous reactions of $\mathrm{NO}_{2}$ on ground surface may play a dominant role. It should be noted that the exact uptake coefficients of $\mathrm{NO}_{2}$ on ground and aerosol surfaces are variable and should be different, and the present analysis simplified this process by treating the ground and aerosol surfaces the same. Our derived uptake coefficients can be regarded as an equivalent $\gamma_{\mathrm{NO} 2}$ on the bulk surface of ground and particles.

\subsection{Daytime HONO budget analysis}

In this section, we examine the potential unknown source(s) of daytime HONO by a detailed budget analysis. Equation (6) summarizes the main factors affecting the ambient concentrations of HONO.

$$
\frac{\mathrm{d}[\mathrm{HONO}]}{\mathrm{dt}}=\mathrm{P}_{\mathrm{emis}}+\mathrm{P}_{\mathrm{OH}+\mathrm{NO}}+\mathrm{P}_{\mathrm{unknown}}-\mathrm{L}_{\mathrm{phot}}-\mathrm{L}_{\mathrm{OH}+\mathrm{HONO}}-\mathrm{L}_{\mathrm{dep}}
$$

Where, $d[\mathrm{HONO}] / \mathrm{dt}$ is the observed rate of change in the HONO mixing ratios; $\mathrm{P}_{\mathrm{x}}$ terms indicate the sources of HONO, consisting of direct emission rate $\left(P_{\text {emis }}\right)$, the gas phase formation rate $\left(P_{O H+N O}, \mathrm{R} 2\right)$, and the unknown $\mathrm{HONO}$ daytime source $\left(P_{\text {unknown }}\right) ; \mathrm{L}_{\mathrm{y}}$ terms denote the sink processes, including the photolysis rate $\left(L_{p h o t}, \mathrm{R} 1\right)$, reaction rate of HONO 
with $\mathrm{OH}\left(L_{\mathrm{OH}+\mathrm{HONO}}, \mathrm{R} 5\right)$, and dry deposition rate $\left(L_{d e p}\right)$. Here we omitted the influence of vertical and horizontal transport since their contributions to ambient HONO are far less than photolysis and gas phase reactions at noontime. The average daytime wind speed in Ji'nan in the present study was $1.7 \mathrm{~m} \mathrm{~s}^{-1}$, so that at a HONO lifetime of about $15 \mathrm{~min}$ at noontime, the horizontal transport had to occur within $1.6 \mathrm{~km}$ (in which no large-scale pollution sources) to reach the site. Dillon et al. (2002) proposed a parameterization for the dilution by background air to estimate the magnitude of vertical transport $\left(\mathrm{T}_{\mathrm{V}}=\mathrm{k}_{\text {(dilution) }}\left([\mathrm{HONO}]-[\mathrm{HONO}]_{\text {background }}\right)\right.$. Even though taking a mean noontime [HONO] level of $1 \mathrm{ppbv}$, a value of $6 \times 10^{-5} \mathrm{ppb} \mathrm{s}^{-1}$ was derived (Dillon et al., 2002; Sörgel et al., 2011), which is much smaller compared to $\mathrm{L}_{\text {phot }}$ $\left(1 \times 10^{-3} \mathrm{ppb} \mathrm{s}^{-1}\right)$.

The noontime data (11:00-14:00 LT) with the strongest solar radiation were chosen to calculate the unknown HONO source strength based on Eq. (7). Here the d[HONO]/dt was approximated by $\Delta \mathrm{HONO} / \Delta \mathrm{t}$, which is the difference of the measured HONO concentrations every 10 minutes (Sörgel et al., 2011).

$\mathrm{P}_{\text {unknown }}=\mathrm{L}_{\text {phot }}+\mathrm{L}_{\mathrm{OH}+\mathrm{HONO}}+\mathrm{L}_{\mathrm{dep}}+\frac{\Delta[\mathrm{HONO}]}{\Delta \mathrm{t}}-\mathrm{P}_{\mathrm{OH}+\mathrm{NO}}-\mathrm{P}_{\mathrm{emis}}$

$=[\mathrm{HONO}]\left(\mathrm{J}_{\mathrm{HONO}}+\mathrm{K}_{\mathrm{OH}+\mathrm{HONO}}[\mathrm{OH}]+\frac{\vartheta_{\mathrm{HONO}}^{\text {ground }}}{\mathrm{H}}\right)+\frac{\Delta[\mathrm{HONO}]}{\Delta \mathrm{t}}-\mathrm{K}_{\mathrm{OH}+\mathrm{NO}}[\mathrm{OH}][\mathrm{NO}]-$ $\frac{\Delta\left[\mathrm{NO}_{\mathrm{X}}\right] \times 0.54 \%}{\Delta \mathrm{t}}$

$[\mathrm{OH}]=\mathrm{a}\left(\mathrm{J}_{\mathrm{O}^{1} \mathrm{D}}\right)^{\alpha}\left(\mathrm{J}_{\mathrm{NO}_{2}}\right)^{\beta} \frac{\mathrm{bNO}_{2}+1}{\mathrm{cNO}_{2}^{2}+\mathrm{dNO}_{2}+1}$

$\left(\alpha=0.83, \beta=0.19, a=4.1 \times 10^{9}, b=140, c=0.41\right.$, and $\left.d=1.7\right)$

Where, $J_{\mathrm{HONO}}$ and $J_{\mathrm{NO}_{2}}$ are the photolysis frequencies of $\mathrm{HONO}$ and $\mathrm{NO}_{2}\left(\mathrm{~s}^{-1}\right)$, respectively. Direct measurements of $J_{\mathrm{HONO}}$ and $J_{\mathrm{NO}_{2}}$ were made in this study except for the period from December 2015 to May 2016. For the reaction of $\mathrm{HONO}$ with $\mathrm{OH}$, a rate constant $K_{O H+H O N O}$ of $6.0 \times 10^{-12} \mathrm{~cm}^{3}$ molecules s $\mathrm{s}^{-1}$ was taken from Atkinson et al. (2004). The $\mathrm{OH}$ mixing ratios were expressed by the $\mathrm{NO}_{2}$ concentrations and photolysis frequencies of $\mathrm{O}_{3}$ and $\mathrm{NO}_{2}$, as shown in Eq. (8) (Alicke et al., 2002). In the present study, the calculated daily peak $\mathrm{OH}$ concentrations were in the range of $0.3-2 \times 10^{7}$ molecules $\mathrm{cm}^{-3}$, which are comparable to those 
measured in the polluted atmospheres of northern China ( $\mathrm{Lu}$ et al., 2013). Nonetheless, it should be noted that the $\mathrm{OH}$ calculation from such empirical equation may be subject to some uncertainty. $L_{\text {dep }}$ was calculated by assuming a HONO daytime dry deposition velocity of 2 $\mathrm{cm} \mathrm{s}^{-1}$ and an effective mixing height of $200 \mathrm{~m}$. Due to the rapid photolysis of HONO at daytime, most of HONO cannot reach the height above $200 \mathrm{~m}$ (Alicke et al., 2002). $K_{O H+N O}$ is the rate constant for the reaction of $\mathrm{OH}$ with $\mathrm{NO}$, using a value of $9.8 \times 10^{-12} \mathrm{~cm}^{3}$ molecules $^{-1} \mathrm{~s}^{-1}$ from (Atkinson et al., 2004). The emission source strength was estimated from the $\mathrm{HONO} / \mathrm{NO}_{\mathrm{X}}$ emission ratio of $0.53 \%$ as determined in Sec. 3.2.

Figure 7 shows the average contributions of all the source and sink terms to the HONO budget in August 2016, when accurate $\mathrm{J}$ values observations were available and elevated daytime HONO were observed. An unknown source $P_{\text {unknown }}$ was clearly the dominant part, accounting for over $80 \%$ of the HONO production. An average $\mathrm{P}_{\text {unknown }}$ value of $2.95 \mathrm{ppb} \mathrm{h}^{-1}$ was derived, which is more than 7 times greater than that of the homogeneous formation rate $\left(P_{O H+N O}, 0.40 \mathrm{ppb} \mathrm{h}^{-1}\right)$. The major loss pathway of HONO was the photolysis with a mean $L_{\text {phot }}$ value of $2.80 \mathrm{ppb} \mathrm{h}^{-1}$, followed by dry deposition $\left(L_{d e p}, 0.49 \mathrm{ppb} \mathrm{h}^{-1}\right)$, and $L_{O H+H O N O}$ was very small and almost less than $3 \%$ of $L_{p h o t}$. The unknown source strength of daytime HONO in Ji'nan is higher than those derived in Santiago, Chile (1.69 $\mathrm{ppb} \mathrm{h}^{-1}$; Elshorbany et al., 2009), Beijing (1.83 $\mathrm{ppb} \mathrm{h}^{-1}$; Hou et al., 2016), and Houston, US (0.61 $\mathrm{ppb} \mathrm{h}^{-1}$; Wong et al., 2012). Some studies have reported much lower $P_{\text {unknown }}$ obtained from a rural site in Guangzhou, China (0.76 $\mathrm{ppb} \mathrm{h}^{-1}$; Li et al., 2012), a mountain site in Hohenpeissenberg, Germany (0.40 $\mathrm{ppb} \mathrm{h}^{-1}$; Acker et al., 2006), and a forest site in Julich, Germany $\left(0.50 \mathrm{ppb} \mathrm{h}^{-1}\right.$; Kleffmann et al., 2005).

We further explored the potential unknown daytime source(s) of HONO based on our measurement data. According to the laboratory studies, heterogeneous reactions of $\mathrm{NO}_{2}$ on wet surfaces should be an important contributor to the ambient HONO concentrations, and the reaction rate is first order in $\mathrm{NO}_{2}$. It has been also proposed that these heterogeneous reactions can be photo-enhanced (Stemmler et al., 2006). Thus, the strength of the unknown HONO source $\left(\mathrm{P}_{\text {unknown }}\right)$ can be expressed by equation (E9), if the heterogeneous reactions were the major HONO sources. 


$$
P_{\text {unknown }} \propto J_{\mathrm{NO}_{2}} *\left[\mathrm{NO}_{2}\right] *\left[\frac{\mathrm{S}}{V}\right]
$$

392 Correlation analysis between $\mathrm{P}_{\text {unknown }}$ and related parameters has been widely adopted to diagnose the potential HONO sources (e.g., Su et al., 2008b). The $\mathrm{NO}_{2}$ concentration $\left(\left[\mathrm{NO}_{2}\right]\right)$ is usually used as an indicator of the heterogeneous reactions on the ground surface since the ground surface to volume ratio $\left(\mathrm{S} / \mathrm{V}_{\mathrm{g}}\right)$ can be assumed to be constant for the well-mixed boundary layer at noontime, whilst $\left[\mathrm{NO}_{2}\right] *\left[\mathrm{~S} / \mathrm{V}_{\mathrm{a}}\right]$ can be taken as a proxy for the HONO formation on the aerosol surface. $\mathrm{JNO}_{2} *\left[\mathrm{NO}_{2}\right]$ and $\mathrm{JNO}_{2} *\left[\mathrm{NO}_{2}\right] *\left[\mathrm{~S} / \mathrm{V}_{\mathrm{a}}\right]$ can be used to infer the photo-enhanced heterogeneous reactions on ground and aerosol surfaces. Figure 8 shows the scatter plots of the calculated $\mathrm{P}_{\text {unknown }}$ versus the abovementioned four indicators for the summer case (i.e., August 2016) when accurate $\mathrm{J}$ value measurements were available. $\mathrm{P}_{\text {unknown }}$ showed a moderate correlation with $\left[\mathrm{NO}_{2}\right]$ with a correlation coefficient $(\mathrm{R})$ of 0.55 , and it was significantly improved after $\mathrm{J}_{\mathrm{NO} 2} *\left[\mathrm{NO}_{2}\right]$ was considered $(\mathrm{R}=0.76)$. When aerosol surface density was taken into account, however, the correlation became even weaker with $\mathrm{R}$ values of 0.40 and 0.43 . This suggests that the photo-enhanced heterogeneous reactions of $\mathrm{NO}_{2}$ on the ground surface played a major role in the daytime HONO formation in Ji'nan in summer.

\subsection{Impact on the primary $\mathrm{OH}$ sources}

Photolysis of $\mathrm{HONO}$ presents an important primary source of $\mathrm{OH}$ in the atmosphere. The elevated levels of daytime HONO imply a sufficient supply of $\mathrm{OH}$ radicals and hence strong atmospheric oxidizing capacity in the urban atmosphere of Ji'nan. Here we assessed the contribution of $\mathrm{HONO}$ photolysis to the $\mathrm{OH}$ production and compared against that from $\mathrm{O}_{3}$ photolysis $\left(\mathrm{O}^{1} \mathrm{D}+\mathrm{H}_{2} \mathrm{O}\right)$, another important $\mathrm{OH}$ source, based on the concurrent observations of $\mathrm{HONO}, \mathrm{O}_{3}, \mathrm{~J}_{\mathrm{HONO}}$ and $\mathrm{J}_{\mathrm{O} 1 \mathrm{D}}$ in summer. The other primary $\mathrm{OH}$ sources, such as photolysis of peroxides and ozonolysis reactions of alkenes, are generally not very important in urban areas, especially at daytime, and were not considered in the present study. We also don't consider the primary sources of $\mathrm{HO}_{2}$ and $\mathrm{RO}_{2}$ radicals (such as photolysis of OVOCs) due to the lack of measurement data for these radical precursors. The net $\mathrm{OH}$ production rate from HONO photolysis $\left(P_{O H}(H O N O)_{n e t}\right)$ was calculated by the source strength subtracting the sink terms due to reactions (R2) and (R5) (Equations 10 and 11). The $\mathrm{OH}$ production rate 
419 from $\mathrm{O}_{3}$ photolysis can be calculated by Equation (12) ( $\mathrm{Su}$ et al., 2008b).

420

421

422

423

424

$\mathrm{P}_{\mathrm{OH}}(\mathrm{HONO})=\mathrm{J}_{\mathrm{HONO}} \times[\mathrm{HONO}]$

$\mathrm{P}_{\mathrm{OH}}(\mathrm{HONO})_{n e t}=\mathrm{P}_{\mathrm{OH}}(\mathrm{HONO})-\mathrm{k}_{\mathrm{NO}+\mathrm{OH}}[\mathrm{NO}][\mathrm{OH}]-\mathrm{k}_{\mathrm{HONO}+\mathrm{OH}}[\mathrm{HONO}][\mathrm{OH}]$

$\mathrm{P}_{\mathrm{OH}}\left(\mathrm{O}_{3}\right)=2 \mathrm{~J}_{\mathrm{O}^{1} \mathrm{D}} \times\left[\mathrm{O}_{3}\right] /\left(1+\mathrm{k}_{3}[\mathrm{M}] / \mathrm{k}_{2}\left[\mathrm{H}_{2} \mathrm{O}\right]\right)$

Figure 9 shows the daytime profiles of $\mathrm{OH}$ production rates from photolysis of $\mathrm{HONO}$ and $\mathrm{O}_{3}$ in the summer (i.e., August 2016) period when accurate $\mathrm{J}$ value measurements were available. Clearly, photolysis of $\mathrm{HONO}$ dominated the daytime $\mathrm{OH}$ production in urban Ji'nan. The mean $P_{O H}(H O N O)$ was $1.88 \mathrm{ppb} \mathrm{h}^{-1}$, almost 3 times higher than $P_{O H}\left(O_{3}\right)$. Furthermore, in contrast to most of the earlier studies which suggested that the contribution of HONO photolysis was mainly concentrated in the early morning and neglected at noon, photolysis of $\mathrm{HONO}$ presents the dominant $\mathrm{OH}$ contributor throughout the daytime at our study site. Even though at noontime in summer, high contributions of HONO photolysis were still found. These results demonstrate the significant role of HONO in the atmospheric oxidizing capacity in the urban atmosphere of Ji'nan.

\section{Summary}

Highly time-resolved continuous field observations of HONO, related air pollutants and meteorological parameters were performed at an urban site of Ji'nan in North China, for a year from September 2015 to August 2016. The measured mean concentration of HONO was $1.15 \mathrm{ppbv}$ with a maximum level of $8.36 \mathrm{ppbv}$. The ambient HONO concentrations presented a seasonal variation with the highest level in winter as well as elevated concentrations in spring (April-May) and summer (August). Well-defined diurnal cycles of HONO with concentration peaks in the early morning and valleys in the afternoon were found for all the four seasons. Direct emissions from vehicle exhaust posed a large contribution to the ambient $\mathrm{HONO}$, with an average emission ratio $\Delta \mathrm{HONO} / \Delta \mathrm{NO}_{\mathrm{X}}$ of $0.53 \%$. During the nighttime, the heterogeneous conversion of $\mathrm{NO}_{2}$ on the ground surface is an important source of HONO. The average conversion frequency of $\mathrm{NO}_{2}$ to $\mathrm{HONO}$ was derived as $0.0068 \mathrm{~h}^{-1}$ from over hundred cases. At daytime, a missing HONO source with an average strength of $2.95 \mathrm{ppb} \mathrm{h}^{-1}$ was derived in summer, which was about seven times larger than the gas phase reactions. Our 
analysis implied that the photo-enhanced heterogeneous reaction of $\mathrm{NO}_{2}$ on the ground surface may be a major source of daytime HONO in summer. Photolysis of HONO presents the predominant $\mathrm{OH}$ contributor not only in the early morning but also throughout the daytime in urban Ji'nan, and hence plays a vital role in the atmospheric oxidation and ozone formation in the polluted urban atmosphere of northern China.

\section{Acknowledgments}

We thank Chuan Yu, Ruihan Zong, Dr. Zheng Xu and Dr. Long Jia for their contributions to the filed study. We are grateful to the European Centre for Medium-Range Weather Forecasts for sharing the boundary layer height data and to the National Center Atmospheric Research for providing the TUV model. This work was funded by the National Natural Science Foundation of China (No. 41505111 and 91544213), the National Key Research and Development Programme of the Ministry of Science and Technology of China (No. 2016YFC0200500), the Natural Science Foundation of Shandong Province (ZR2014BQ031), the Qilu Youth Talent Program of Shandong University, and the Jiangsu Collaborative Innovation Center for Climate Change.

\section{References}

Acker, K., Febo, A., Trick, S., Perrino, C., Bruno, P., Wiesen, P., Möller, D., Wieprecht, W., Auel, R., Giusto, M., Geyer, A., Platt, U., Allegrini, I., 2006a. Nitrous acid in the urban area of Rome. Atmospheric Environment 40, 3123-3133.

Acker, K., Möller, D., Wieprecht, W., Meixner, F.X., Bohn, B., Gilge, S., Plass - Dülmer, C., Berresheim, H., 2006b. Strong daytime production of $\mathrm{OH}$ from $\mathrm{HNO}_{2}$ at a rural mountain site. Geophysical Research Letters 33, L02809.

Alicke, B., Platt, U., Stutz, J., 2002. Impact of nitrous acid photolysis on the total hydroxyl radical budget during the Limitation of Oxidant Production/Pianura Padana Produzione di Ozono study in Milan. Journal of Geophysical Research 107 (D22), 8196.

Ammann, M., Kalberer, M., Jost, D., Tobler, L., Rössler, E., Piguet, D., Gäggeler, H., Baltensperger, U., 1998. Heterogeneous production of nitrous acid on soot in polluted air masses. Nature 395, 157-160.

Ammann, M., Rössler, E., Strekowski, R., George, C., 2005. Nitrogen dioxide multiphase chemistry: uptake 
kinetics on aqueous solutions containing phenolic compounds. Physical Chemistry Chemical Physics 7 , 2513-2518.

Atkinson, R., Baulch, D.L., Cox, R.A., Crowley, J.N., Hampson, R. F., Hynes, R.G., Jenkin, M. E., Rossi, M. J., Troe, J., 2004. Evaluated kinetic and photochemical data for atmospheric chemistry: Volume I - gas phase reactions of Ox, HOx, NOx and SOx species. Atmospheric Chemistry and Physics 4, 1461-1738.

Beine, H.J., Amoroso, A., Dominé, F., King, M.D., Nardino, M., Ianniello, A., France, J.L., 2006. Surprisingly small HONO emissions from snow surfaces at Browning Pass, Antarctica. Atmospheric Chemistry and Physics 6, 2569-2580.

Bernard, F., Cazaunau, M., Grosselin, B., Zhou, B., Zheng, J., Liang, P., Zhang, Y., Ye, X., Daele, V., Mu, Y., Zhang, R., Chen, J., Mellouki, A., 2016. Measurements of nitrous acid (HONO) in urban area of Shanghai, China. Environmental Science and Pollution Research 23 (6), 5818-5829.

Dillon, M.B., Lamanna, M.S., Schade, G.W., Goldstein, A., Cohen, R.C., 2002. Chemical evolution of the Sacramento urban plume: Transport and oxidation. Journal of Geophysical Research 107 (D5), 40-45. Elshorbany, Y.F., Kurtenbach, R., Wiesen, P., Lissi, E., Rubio, M., Villena, G., Gramsch, E., Rickard, A.R., Pilling, M.J., Kleffmann, J., 2009. Oxidation capacity of the city air of Santiago, Chile. Atmospheric Chemistry and Physics 9, 2257-2273.

Elshorbany, Y.F., Kleffmann, J., Kurtenbach, R., Lissi, E., Rubio, M., Villena, G., Gramsch, E., Rickard, A.R., Pilling, M.J., Wiesen, P., 2010. Seasonal dependence of the oxidation capacity of the city of Santiago de Chile. Atmospheric Environment 44, 5383-5394.

Finlayson-Pitts, B.J., Wingen, L.M., Sumner, A.L., Syomin, D., Ramazan, K.A., 2003. The heterogeneous hydrolysis of $\mathrm{NO}_{2}$ in laboratory systems and in outdoor and indoor atmospheres: An integrated mechanism. Physical Chemistry Chemical Physics 5, 223-242.

George, C., Strekowski, R.S., Kleffmann, J., Stemmler, K., Ammann, M., 2005. Photoenhanced uptake of gaseous $\mathrm{NO}_{2}$ on solid organic compounds: a photochemical source of HONO? Faraday Discussions 130, 195-210.

Han, C., Liu, Y., He, H., 2013. Heterogeneous photochemical aging of soot by $\mathrm{NO}_{2}$ under simulated sunlight. Atmospheric Environment 64, 270-276.

Heland, J., Kleffmann, J., Kurtenbach, R., Wiesen, P., 2001. A new instrument to measure gaseous nitrous acid (HONO) in the atmosphere. Environmental Science \& Technology 35, 3207-3212.

Hendrick, F., Müller, J.F., Clémer, K., Wang, P., De Mazière, M., Fayt, C., Gielen, C., Hermans, C., Ma, J.Z., 
Pinardi, G., Stavrakou, T., Vlemmix, T., Van Roozendael, M., 2014. Four years of ground-based MAX-DOAS observations of $\mathrm{HONO}$ and $\mathrm{NO}_{2}$ in the Beijing area. Atmospheric Chemistry and Physics 14, 765-781.

Hou, S., Tong, S., Ge, M., An, J., 2016. Comparison of atmospheric nitrous acid during severe haze and clean periods in Beijing, China. Atmospheric Environment 124, 199-206.

Kleffmann, J., Gavriloaiei, T., Hofzumahaus, A., Holland, F., Koppmann, R., Rupp, L., Schlosser, E., Siese, M., Wahner, A., 2005. Daytime formation of nitrous acid: A major source of $\mathrm{OH}$ radicals in a forest. Geophysical Research Letters 32, L05818.

Kurtenbach, R., Becker, K.H., Gomes, J.A.G., Kleffmann, J., Lörzer, J.C., Spittler, M., Wiesen, P., Ackermann, R., Geyer, A., Platt, U., 2001. Investigations of emissions and heterogeneous formation of HONO in a road traffic tunnel. Atmospheric Environment 35, 3385-3394.

Li, G., Lei, W., Zavala, M., Volkamer, R., Dusanter, S., Stevens, P., Molina, L.T., 2010. Impacts of HONO sources on the photochemistry in Mexico City during the MCMA-2006/MILAGO Campaign. Atmospheric Chemistry and Physics 10, 6551-6567.

Li, X., Brauers, T., Häseler, R., Bohn, B., Fuchs, H., Hofzumahaus, A., Holland, F., Lou, S., Lu, K.D., Rohrer, F., Hu, M., Zeng, L.M., Zhang, Y.H., Garland, R.M., Su, H., Nowak, A., Wiedensohler, A., Takegawa, N., Shao, M., Wahner, A., 2012. Exploring the atmospheric chemistry of nitrous acid (HONO) at a rural site in Southern China. Atmospheric Chemistry and Physics 12, 1497-1513.

Li, X., Rohrer, F., Hofzumahaus, A., Brauers, T., Häseler, R., Bohn, B., Broch, S., Fuchs, H., Gomm, S., Holland, F., Jäger, J., Keutsch, F.N., Lohse, I., Lu, K., Tillmann, R., Wegener, R., Wolfe, G.M., Mentel, T.F., Kiendler-Scharr, A., Wahner, A., 2014. Missing gas-phase source of HONO inferred from Zeppelin measurements in the troposphere. Science 344, 292-296.

Liu, Z., Wang, Y., Costabile, F., Amoroso, A., Zhao, C., Huey, L.G., Stickel, R., Liao, J., Zhu, T., 2014. Evidence of aerosols as a media for rapid daytime HONO production over China. Environmental Science \& Technology 48, 14386-14391.

Lu, K.D., Hofzumahaus, A., Holland, F., Bohn, B., Brauers, T., Fuchs, H., Hu, M., Seler, R.H., Kita, K., Kondo, Y., 2013. Missing $\mathrm{OH}$ source in a suburban environment near Beijing: observed and modelled $\mathrm{OH}$ and $\mathrm{HO}_{2}$ concentrations in summer 2006. Atmospheric Chemistry Physics 13, 1057-1080.

Ma, Q., Wang, T., Liu, C., He, H., Wang, Z., Wang, W., Liang, Y., 2017. $\mathrm{SO}_{2}$ initiates the efficient conversion of $\mathrm{NO}_{2}$ to $\mathrm{HONO}$ on $\mathrm{MgO}$ surface. Environmental Science \& Technology 51, 3767-3775. 
Monge, M.E., D'Anna, B., Mazri, L., Giroir-Fendler, A., Ammann, M., Donaldson, D.J., George, C., 2010. Light changes the atmospheric reactivity of soot. Proceedings of the National Academy of Sciences of the United States of America 107, 6605-6609.

Ndour, M., D'Anna, B., George, C., Ka, O., Balkanski, Y., Kleffmann, J., Stemmler, K., Ammann, M., 2008. Photoenhanced uptake of $\mathrm{NO}_{2}$ on mineral dust: Laboratory experiments and model simulations. Geophysical Research Letters 35, L05812.

Nie, W., Wang, T., Xue, L., Ding, A., Wang, X., Gao, X., Xu, Z., Yu, Y., Yuan, C., Zhou, Z., Gao, R., Liu, X., Wang, Y., Fan, S., Poon, S., Zhang, Q., Wang, W., 2012. Asian dust storm observed at a rural mountain site in southern China: chemical evolution and heterogeneous photochemistry. Atmospheric Chemistry and Physics 12, 11985-11995.

Pagsberg, P., Bjergbakke, E., Ratajczak, E., Sillesen, A., 1997. Kinetics of the gas phase reaction OH + NO(+M) $\rightarrow \mathrm{HONO}(+\mathrm{M})$ and the determination of the UV absorption cross sections of HONO. Chemical Physics Letters 272, 383-390.

Qin, M., Xie, P., Su, H., Gu, J., Peng, F., Li, S., Zeng, L., Liu, J., Liu, W., Zhang, Y., 2009. An observational study of the HONO-NO ${ }_{2}$ coupling at an urban site in Guangzhou City, South China. Atmospheric Environment 43, 5731-5742.

Rappenglück, B., Lubertino, G., Alvarez, S., Golovko, J., Czader, B., Ackermann, L., 2013. Radical precursors and related species from traffic as observed and modeled at an urban highway junction. Journal of the Air \& Waste Management Association 63, 1270-1286.

Sörgel, M., Regelin, E., Bozem, H., Diesch, J.M., Drewnick, F., Fischer, H., Harder, H., Held, A., Hosaynali-Beygi, Z., Martinez, M., Zetzsch, C., 2011. Quantification of the unknown HONO daytime source and its relation to $\mathrm{NO}_{2}$. Atmospheric Chemistry and Physics 11, 10433-10447.

Stemmler, K., Ammann, M., Donders, C., Kleffmann, J., George, C., 2006. Photosensitized reduction of nitrogen dioxide on humic acid as a source of nitrous acid. Nature 440, 195-198.

Su, H., Cheng, Y.F., Cheng, P., Zhang, Y.H., Dong, S., Zeng, L.M., Wang, X., Slanina, J., Shao, M., Wiedensohler, A., 2008a. Observation of nighttime nitrous acid (HONO) formation at a non-urban site during PRIDE-PRD2004 in China. Atmospheric Environment 42, 6219-6232.

Su, H., Cheng, Y.F., Shao, M., Gao, D.F., Yu, Z.Y., Zeng, L.M., Slanina, J., Zhang, Y.H., Wiedensohler, A., 2008b. Nitrous acid (HONO) and its daytime sources at a rural site during the 2004 PRIDE - PRD experiment in China. Journal of Geophysical Research 113, D14312. 
Su, H., Cheng, Y., Oswald, R., Behrendt, T., Trebs, I., Meixner, F.X., Andreae, M.O., Cheng, P., Zhang, Y., Pöschl, U., 2011. Soil nitrite as a source of atmospheric HONO and OH radicals. Science 333, 1616-1618.

Tong, S., Hou, S., Zhang, Y., Chu, B., Liu, Y., He, H., Zhao, P., Ge, M., 2015. Comparisons of measured nitrous acid (HONO) concentrations in a pollution period at urban and suburban Beijing, in autumn of 2014. Science China Chemistry 58, 1393-1402.

Tong, S., Hou, S., Zhang, Y., Chu, B., Liu, Y., He, H., Zhao, P., Ge, M., 2016. Exploring the nitrous acid (HONO) formation mechanism in winter Beijing: direct emissions and heterogeneous production in urban and suburban areas. Faraday Discussions 189, 213-230.

VandenBoer, T.C., Brown, S.S., Murphy, J.G., Keene, W.C., Young, C.J., Pszenny, A.A.P., Kim, S., Warneke, C., de Gouw, J.A., Maben, J.R., Wagner, N.L., Riedel, T.P., Thornton, J.A., Wolfe, D.E. Dube, W.P., Ozturk, F., Brock, C.A., Grossberg, N., Lefer, B., Lerner B., Middlebrook, A.M., Roberts, J.M., 2013. Understanding the role of the ground surface in HONO vertical structure: High resolution vertical profiles during NACHTT - 11. Journal of Geophysical Research 118, 10,155-10,171.

Voogt, J.A., Oke, T.R., 1997. Complete urban surface temperatures. Journal of Applied Meteorology 36, $1117-1132$.

Wang, L., Wen, L., Xu, C., Chen, J., Wang, X., Yang, L., Wang, W., Yang, X., Sui, X., Yao, L., Zhang, Q., 2015. HONO and its potential source particulate nitrite at an urban site in North China during the cold season. Science of the Total Environment 538, 93-101.

Wang, S., Zhou, R., Zhao, H., Wang, Z., Chen, L., Zhou, B., 2013. Long-term observation of atmospheric nitrous acid (HONO) and its implication to local $\mathrm{NO}_{2}$ levels in Shanghai, China. Atmospheric Environment $77,718-724$.

Wong, K.W., Oh, H.-J., Lefer, B.L., Rappenglück, B., Stutz, J., 2011. Vertical profiles of nitrous acid in the nocturnal urban atmosphere of Houston, TX. Atmospheric Chemistry and Physics 11, 3595-3609.

Xu, Z., Wang, T., Wu, J., Xue, L., Chan, J., Zha, Q., Zhou, S., Louie, P.K.K, Luk, C.W.Y, 2015. Nitrous acid (HONO) in a polluted subtropical atmosphere: Seasonal variability, direct vehicle emissions and heterogeneous production at ground surface. Atmospheric Environment 106, 100-109.

Xue, L., Gu, R., Wang, T., Wang, X., Saunders, S., Blake, D., Louie, P.K.K., Luk, C.W.Y., Simpson, I., Xu, Z., Wang, Z., Gao, Y., Lee, S., Mellouki, A., Wang, W., 2016. Oxidative capacity and radical chemistry in the polluted atmosphere of Hong Kong and Pearl River Delta region: analysis of a severe photochemical smog episode. Atmospheric Chemistry and Physics 16, 9891-9903. 
595

596

597

598

599

600

601

602

603

604

605

606

607

608

Xue, L., Wang, T., Zhang, J.M., Zhang, X.C., Deliger, Poon, C.N., Ding, A.J., Zhou, X.H., Wu, W.S., Tang, J., Zhang, Q.Z., Wang, W.X., 2011. Source of surface ozone and reactive nitrogen speciation at Mount Waliguan in western China: new insights from the 2006 summer study. Journal of Geophysical Research 116, D07306.

Yu, Y., Galle, B., Panday, A., Hodson, E., Prinn, R., Wang, S., 2009. Observations of high rates of $\mathrm{NO}_{2}-\mathrm{HONO}$ conversion in the nocturnal atmospheric boundary layer in Kathmandu, Nepal. Atmospheric Chemistry and Physics 9, 6401-6415.

Zhang, L., Wang, T., Zhang, Q., Zheng, J., Xu, Z., Lv, M., 2016. Potential Sources of Nitrous Acid (HONO) and Their Impacts on Ozone: A WRF - Chem study in a Polluted Subtropical Region. Journal of Geophysical Research 121, 3645-3662.

Zhou, X., Beine, H.J., Honrath, R.E., Fuentes, J.D., Simpson, W., Shepson, P.B., Bottenheim, J.W., 2001. Snowpack photochemical production of HONO: A major source of $\mathrm{OH}$ in the Arctic boundary layer in springtime. Geophysical Research Letters 28, 4087-4090. 
Table 1. Overview of the measured HONO and NOx levels in urban Ji'nan and comparison with other studies.

\begin{tabular}{|c|c|c|c|c|c|c|c|c|c|c|c|c|}
\hline \multirow{2}{*}{ Location } & \multirow{2}{*}{ Time } & \multicolumn{2}{|c|}{$\mathrm{HONO}(\mathrm{ppb})$} & \multicolumn{2}{|c|}{$\mathrm{NO}_{2}(\mathrm{ppb})$} & \multicolumn{2}{|c|}{$\mathrm{NO}_{\mathrm{X}}(\mathrm{ppb})$} & \multicolumn{2}{|c|}{$\mathrm{HONO} / \mathrm{NO}_{2}$} & \multicolumn{2}{|c|}{$\mathrm{HONO} / \mathrm{NO}_{\mathrm{X}}$} & \multirow{2}{*}{ Ref. } \\
\hline & & $\mathrm{N}$ & $\mathrm{D}$ & $\mathrm{N}$ & $\mathrm{D}$ & $\mathrm{N}$ & $\mathrm{D}$ & $\mathrm{N}$ & $\mathrm{D}$ & $\mathrm{N}$ & $\mathrm{D}$ & \\
\hline Santiago, Chile (urban) & Mar-Jun 2005 & 3.00 & 1.50 & 30.0 & 20.0 & 200.0 & 40.0 & 0.100 & 0.075 & 0.015 & 0.038 & 1 \\
\hline Rome, Italy (urban) & May-Jun 2001 & 1.00 & 0.15 & 27.2 & 4.0 & 51.2 & 4.2 & 0.037 & 0.038 & 0.020 & 0.024 & 2 \\
\hline Kathmandu, Nepal (urban) & Jan-Feb 2003 & 1.74 & 0.35 & 17.9 & 8.6 & 20.1 & 13.0 & 0.097 & 0.041 & 0.087 & 0.027 & 3 \\
\hline Shanghai, China (urban) & Oct 2009 & 1.50 & 1.00 & 41.9 & 30.0 & l & l & 0.038 & 0.032 & l & l & 4 \\
\hline Guangzhou, China (urban) & Jun 2006 & 3.5 & 2.00 & 20.0 & 30.0 & l & l & 0.175 & 0.067 & l & l & 5 \\
\hline Beijing, China (urban) & Oct-Nov 2014 & 1.75 & 0.93 & 37.6 & 35.3 .0 & 94.5 & 53.4 & 0.047 & 0.026 & 0.019 & 0.017 & 6 \\
\hline Xinken, China (suburban) & Oct-Nov 2004 & 1.30 & 0.80 & 34.8 & 30.0 & 37.8 & 40.0 & 0.037 & 0.027 & 0.034 & 0.020 & 7 \\
\hline Milan, Italy (suburban) & May-Jun 1998 & 0.92 & 0.14 & 33.2 & 18.3 & 117.5 & 23.4 & 0.028 & 0.008 & 0.008 & 0.006 & 8 \\
\hline \multirow[t]{3}{*}{ Backgarden, China (rural) } & Jul 2006 & 0.95 & 0.24 & 16.5 & 4.5 & 20.9 & 5.5 & 0.057 & 0.053 & 0.045 & 0.043 & 9 \\
\hline & Sep 2015-Aug 2016 & 1.28 & 0.99 & 31.0 & 25.8 & 46.4 & 40.6 & 0.079 & 0.056 & 0.040 & 0.035 & 10 \\
\hline & Sep-Nov 2015 (autumn) & 0.87 & 0.66 & 25.4 & 23.2 & 38. & 37.5 & 0.049 & 0.034 & 0.034 & 0.022 & 10 \\
\hline \multirow[t]{3}{*}{ Ji'nan, China (urban) } & Dec 2015-Feb 2016 (winter) & 2.15 & 1.35 & 41.1 & 34.6 & 78.5 & 64.8 & 0.056 & 0.047 & 0.034 & 0.031 & 10 \\
\hline & Mar-May 2016 (spring) & 1.24 & 1.04 & 35.8 & 25.8 & 47.3 & 36.0 & 0.046 & 0.052 & 0.035 & 0.041 & 10 \\
\hline & Jun-Aug 2016 (summer) & 1.20 & 1.01 & 22.5 & 19.0 & 29.1 & 25.8 & 0.106 & 0.079 & 0.060 & 0.049 & 10 \\
\hline
\end{tabular}

$\mathrm{N}$ : nighttime (18:00-06:00, LT); D: daytime (06:00-18:00, LT)

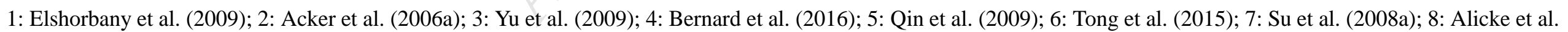
(2002); 9: Li et al. (2012); 10: this study. 
Table 2. The emission ratios $\Delta \mathrm{HONO} / \Delta \mathrm{NO}_{\mathrm{X}}$ of fresh vehicle plumes.

\begin{tabular}{ccccc}
\hline Date & Local Time & $\Delta \mathrm{NO} / \Delta \mathrm{NO}_{\mathrm{X}}$ & $\mathrm{R}^{2}$ & $\Delta \mathrm{HONO} / \Delta \mathrm{NO}_{\mathrm{X}}(\%)$ \\
\hline $11 / 03 / 2015$ & $06: 08-07: 45$ & 0.89 & 0.91 & 0.29 \\
$11 / 05 / 2015$ & $06: 00-07: 30$ & 0.92 & 0.84 & 0.63 \\
$11 / 17 / 2015$ & $06: 00-07: 30$ & 1 & 0.95 & 0.75 \\
$11 / 20 / 2015$ & $06: 00-07: 15$ & 0.92 & 0.72 & 0.59 \\
$12 / 06 / 2015$ & $06: 00-07: 48$ & 0.83 & 0.75 & 0.87 \\
$12 / 08 / 2015$ & $06: 02-07: 30$ & 0.95 & 0.61 & 0.58 \\
$12 / 25 / 2015$ & $06: 00-07: 30$ & 0.94 & 0.72 & 0.30 \\
$12 / 31 / 2015$ & $06: 00-07: 30$ & 0.96 & 0.94 & 0.47 \\
$01 / 02 / 2016$ & $06: 00-07: 30$ & 1 & 0.61 & 0.46 \\
$01 / 20 / 2016$ & $06: 44-07: 48$ & 0.92 & 0.96 & 0.71 \\
$01 / 21 / 2016$ & $06: 26-07: 56$ & 0.94 & 0.58 & 0.54 \\
$01 / 27 / 2016$ & $07: 00-08: 12$ & 0.89 & 0.77 & 0.19 \\
\hline
\end{tabular}



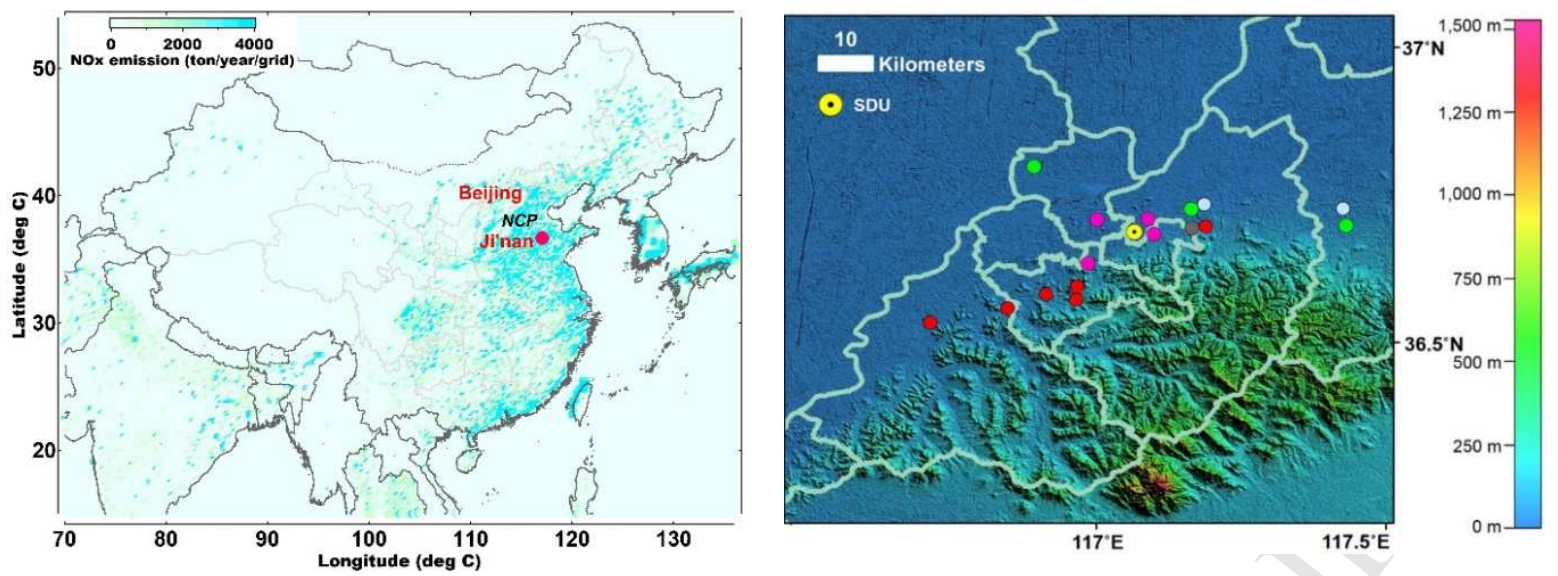

Figure 1. Locations of Ji'nan and the sampling site. The left map is color-coded by the anthropogenic NOx emissions (Zhang et al., 2009), while the right is color-coded by the geographical height. The large industrial sources are labeled with different colors, including steel plants (light blue), thermal power plants (pink), cement plants (red), oil refineries (grey) and chemical plants (green).

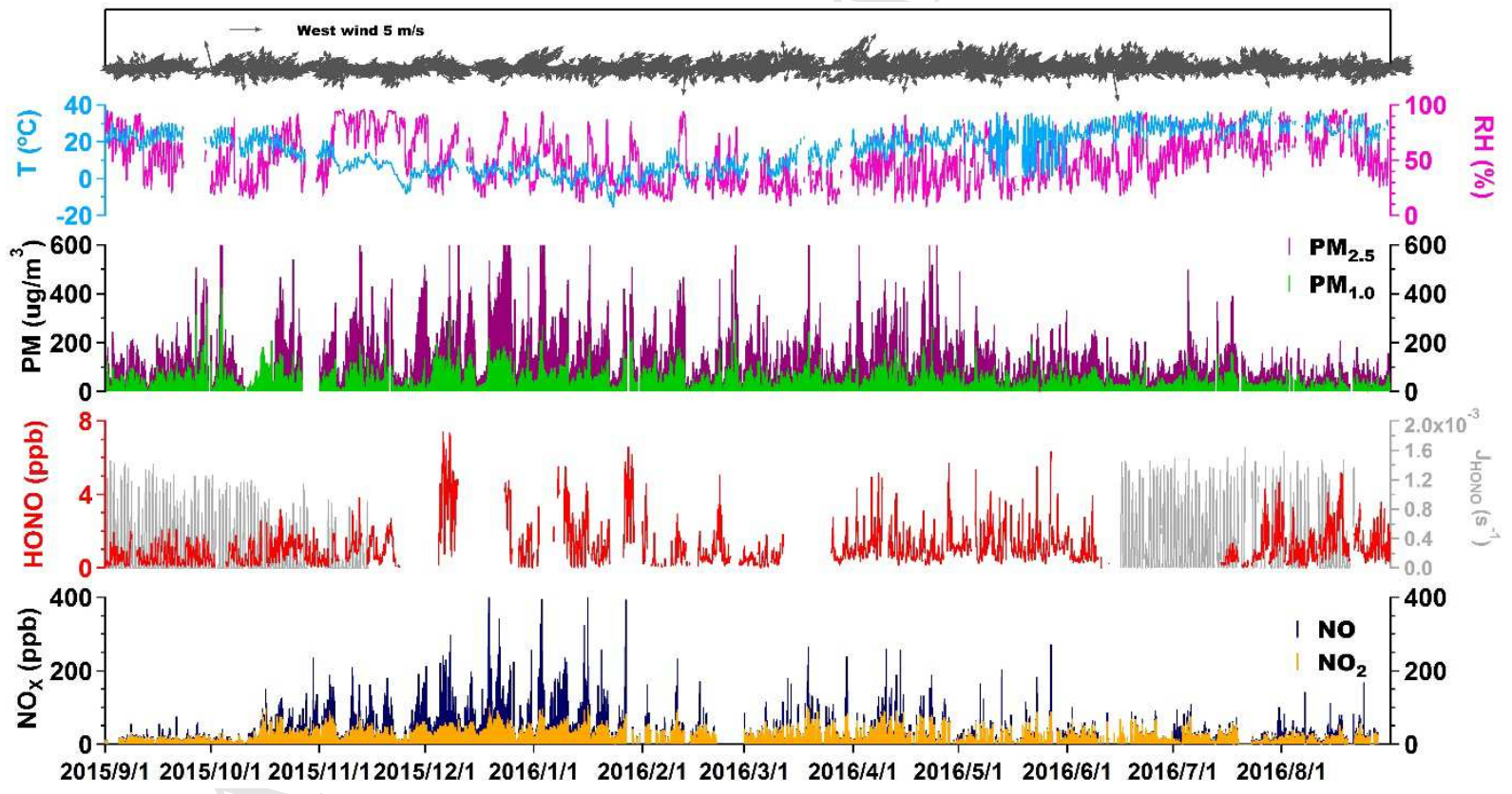

Figure 2. Time series of $\mathrm{HONO}, \mathrm{NO}, \mathrm{NO}_{2}, \mathrm{PM}_{2.5}, \mathrm{PM}_{1.0}, \mathrm{~J}_{\mathrm{HONO}}$, temperature $(\mathrm{T})$, relative humidity (RH) and surface wind in Ji'nan from September 2015 to August 2016. The data gap is mainly due to the maintenance of the instruments. 

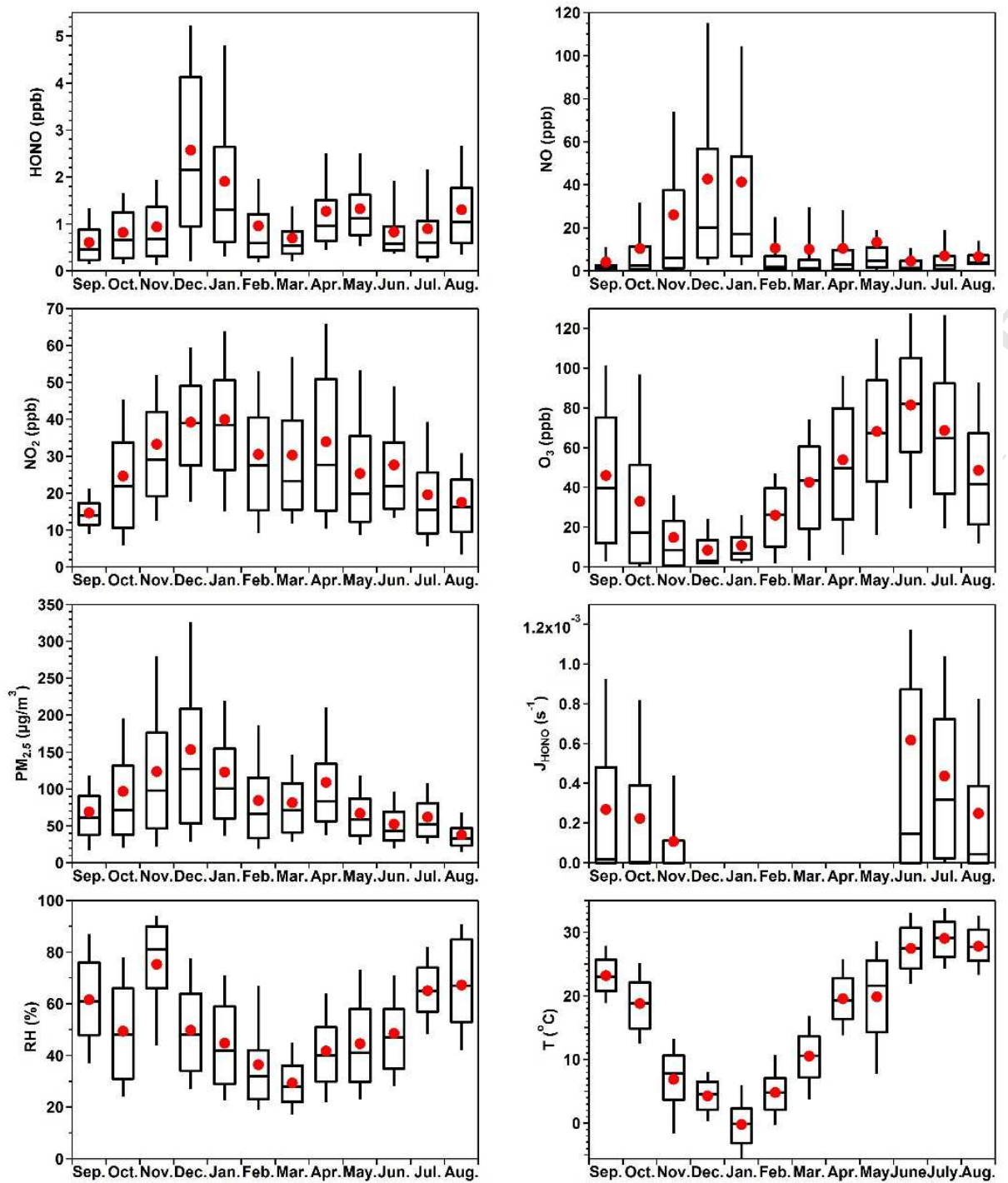

Figure 3. Seasonal variations of $\mathrm{HONO}, \mathrm{NO}, \mathrm{NO}_{2}, \mathrm{O}_{3}, \mathrm{PM}_{2.5}, \mathrm{~J}_{\mathrm{HONO}}$ and $\mathrm{RH}$ and $\mathrm{T}$. The box plot provides the $10 \%, 25 \%, 50 \%, 75 \%$ and $90 \%$ the data, while the red dots indicate the average concentrations. 

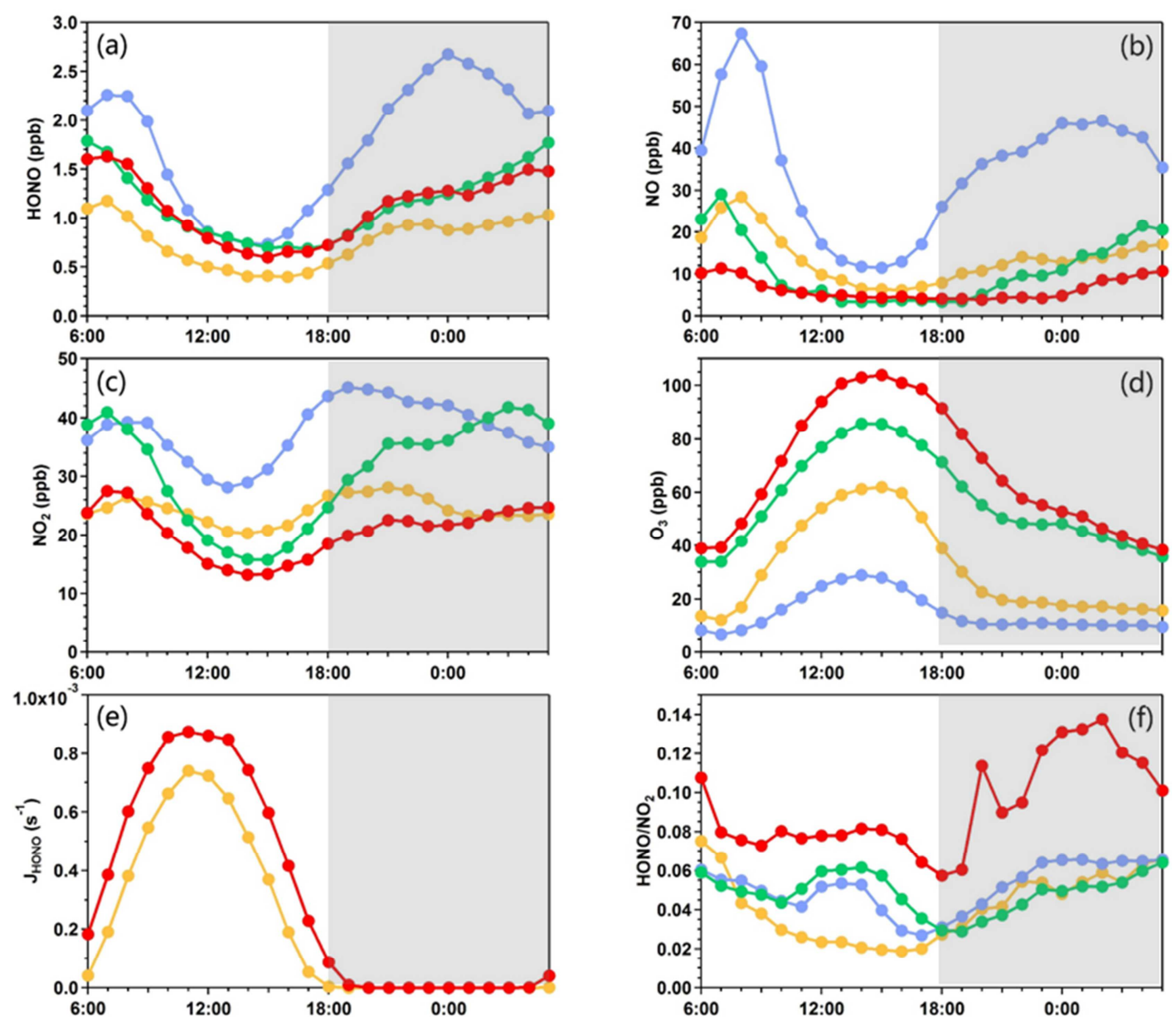

Autumn $\odot$ Winter $\bullet$ Spring $\bullet$ Summer

Figure 4. Diurnal variations of (a) $\mathrm{HONO}$, (b) $\mathrm{NO}$, (c) $\mathrm{NO}_{2}$, (d) $\mathrm{O}_{3}$, (e) $\mathrm{J}_{\mathrm{HONO}}$, and (f) $\mathrm{HONO} / \mathrm{NO}_{2}$ in the four seasons. The grey shaded area indicates the nighttime period (18:00-06:00 LT; note that the exact nighttime periods varied with different seasons). 

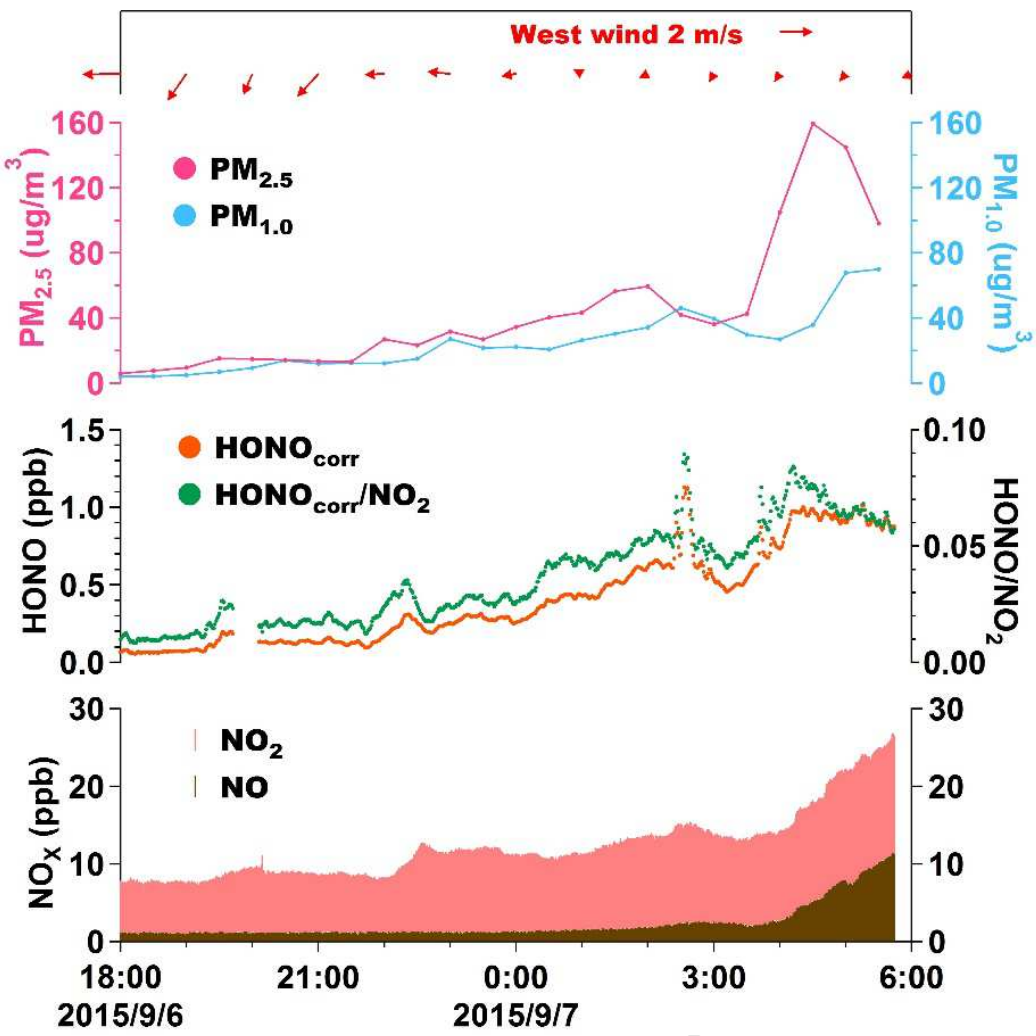

Figure 5. A case of the determination of heterogeneous $\mathrm{NO}_{2}$-to-HONO conversion frequency at nighttime.

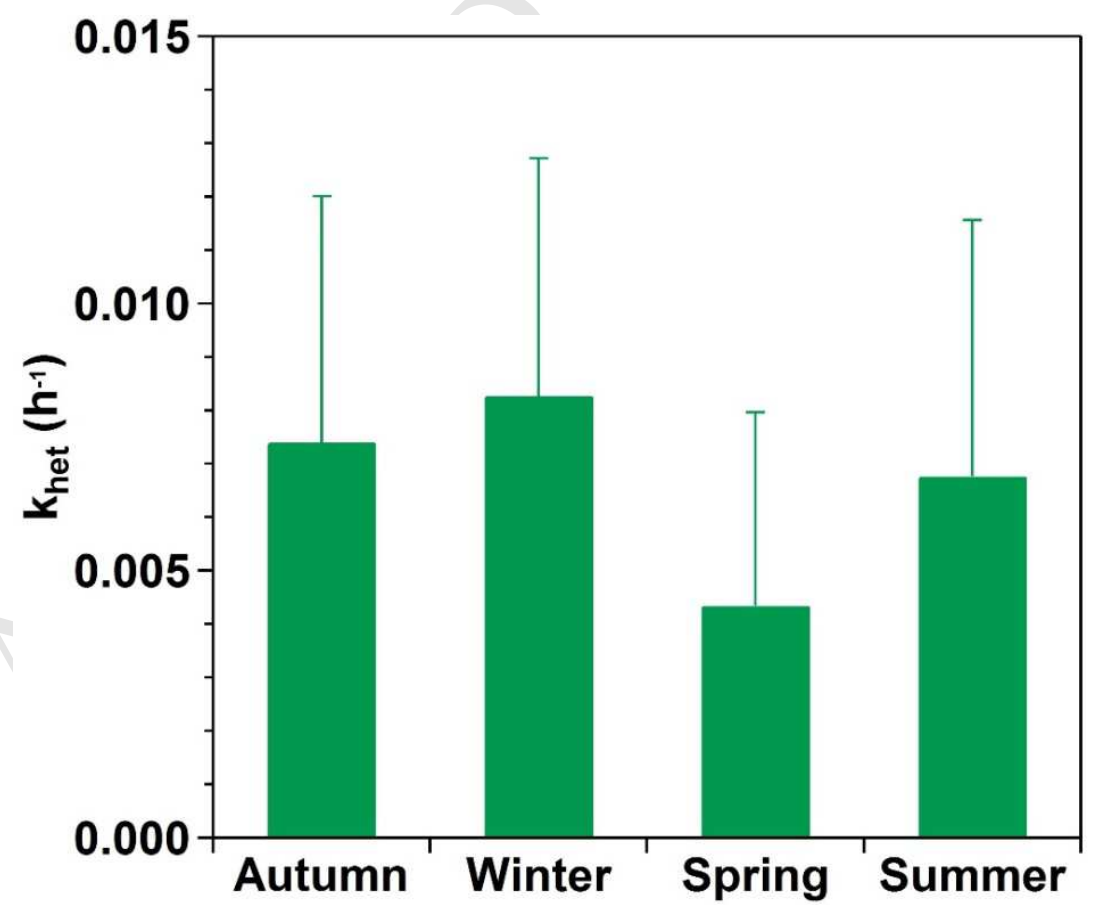

Figure 6. Seasonal variation of the $\mathrm{NO}_{2}$-to-HONO conversion frequency $\left(\mathrm{k}_{\text {het }}\right)$ in Ji'nan. 


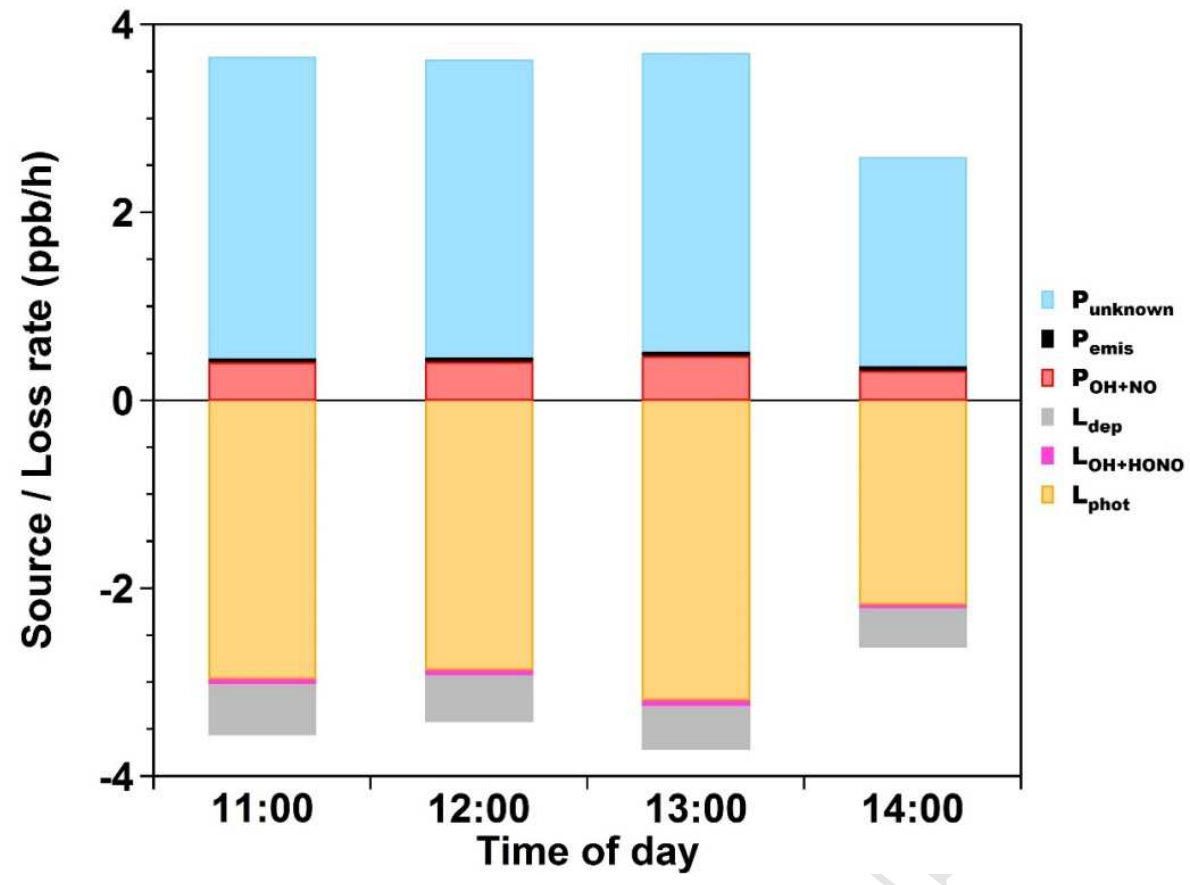

Figure 7. Average daytime HONO budget at noon (11:00-14:00 LT) in August 2016.
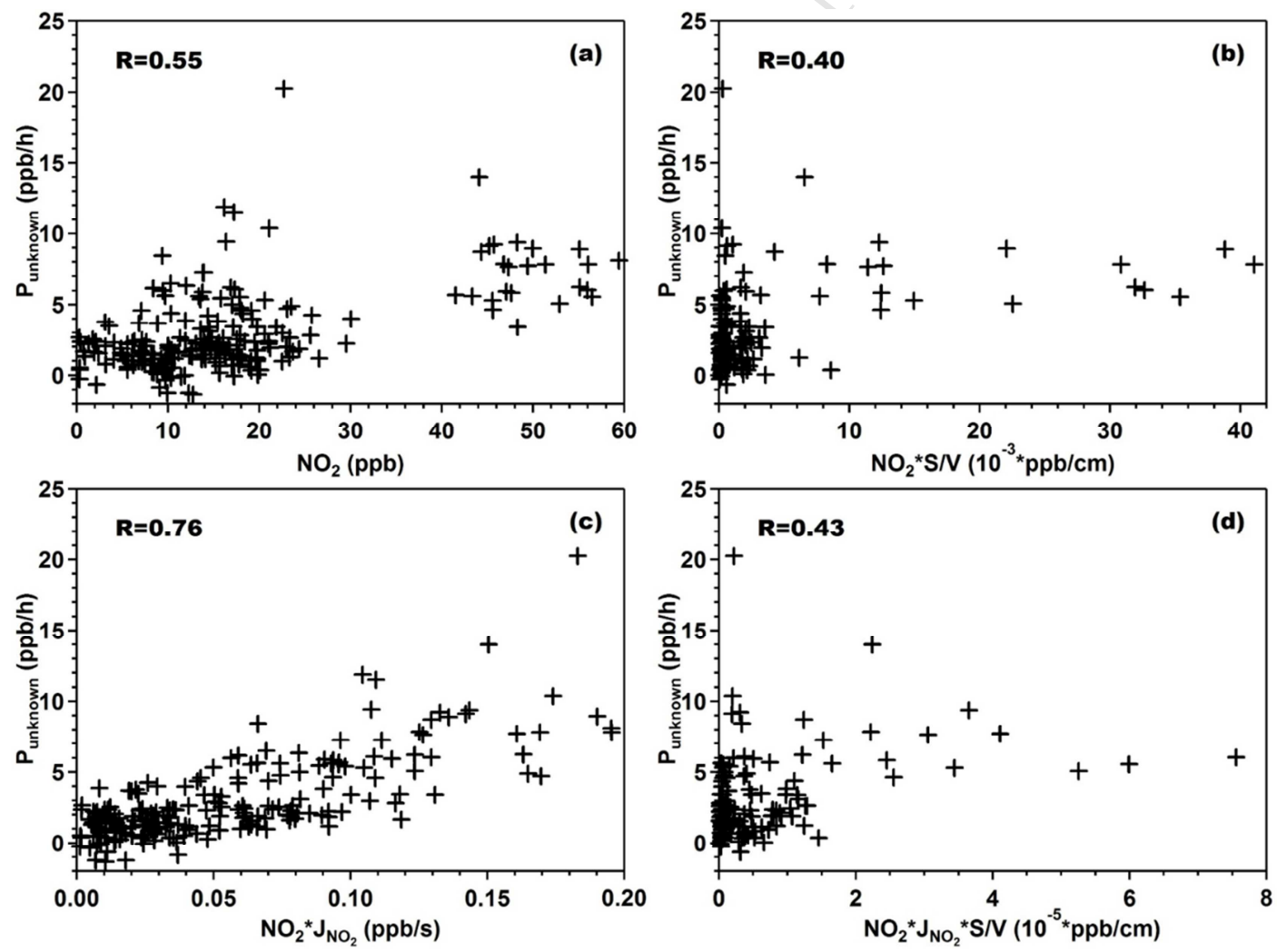

Figure 8. Scatter plots of the unknown daytime HONO source strength $\left(\mathrm{P}_{\text {unknown }}\right)$ with (a) $\mathrm{NO}_{2}$, (b) $\mathrm{NO}_{2} *(\mathrm{~S} / \mathrm{V})_{\mathrm{a}}$, (c) $\mathrm{NO}_{2} * \mathrm{~J}_{\mathrm{NO} 2}$, and (d) $\mathrm{NO}_{2} * \mathrm{~J}_{\mathrm{NO}} *(\mathrm{~S} / \mathrm{V})_{\mathrm{a}}$ during August 2016. 


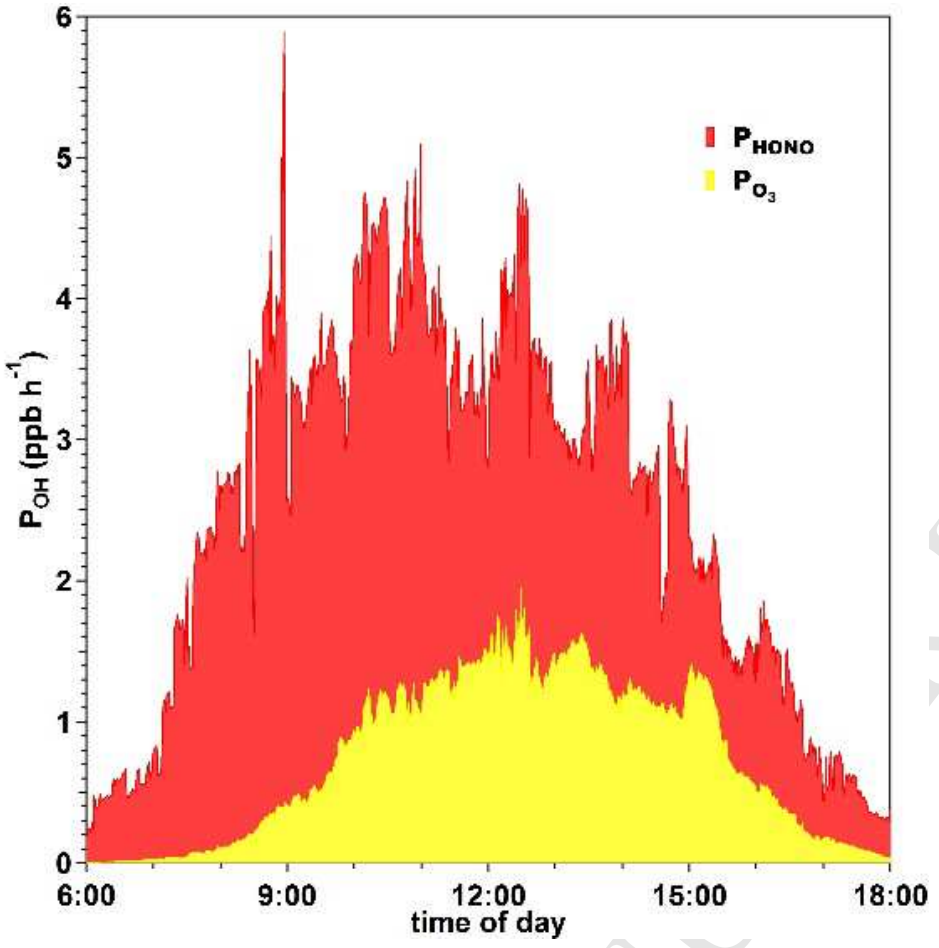

Figure 9. Average $\mathrm{OH}$ production rates from photolysis of $\mathrm{HONO}$ and $\mathrm{O}_{3}$ in summer (August 2016). 


\section{Highlights:}

- One-year continuous measurements of HONO were made at a typical urban site in northern China.

- Seasonal and diurnal variations, vehicle emission factors, heterogeneous formation, and daytime sources were examined based on a large observational data set.

- A strong missing daytime source was needed to explain the measured HONO concentrations.

- HONO photolysis is the dominant $\mathrm{OH}$ source throughout the daytime. 